\title{
La responsabilidad precontractual por ruptura de las tratativas preliminares
}

Luis Parraguez Ruiz

\section{Resumen}

Con fundamento en el estándar de la buena fe se predica que la fase precontractual impone una serie de deberes de distinta naturaleza cuya infracción da lugar a responsabilidad civil. El Código civil ecuatoriano no ha previsto esta categoría de deberes y ha reducido la exigencia de la buena fe a la ejecución del contrato. No obstante, hay razones para sostener esta responsabilidad en el ordenamiento nacional. Aceptado aquello la cuestión a dilucidar es la naturaleza de dicha responsabilidad punto en el cual la doctrina ofrece diferentes tesis, prevaleciendo el criterio de que se trata de una hipótesis de responsabilidad extracontractual, lo que permite sustentarla en el derecho nacional con apoyo en los artículos 2214 y siguientes del Código civil.

Palabras clave: buena fe, tratativas, deberes precontractuales, deber de información, responsabilidad precontractual, culpa in contrahendo

\begin{abstract}
Based on the standard of good faith, it is preached that the pre-contractual stage imposes a number of duties of different nature which violation gives rise to civil liability. The Ecuadorian Civil Code does not provide this category of duties and has limited the requirement of good faith to the execution phase of the contract. However, there are reasons to hold the existence of this responsibility in the national system. If that is accepted, the question to be resolved is the nature of the liability. On this point, the doctrine offers different thesis and the prevailing view that this is a type of tort. Articles 2214 and following of the Civil Code support this hypothesis in national law.
\end{abstract}

Keywords: good faith, negotiations, pre-contractual duties, duty to inform, pre-contractual responsibility, pre-contractual liability.

\footnotetext{
* Doctor por la Universidad de Salamanca. Profesor de Derecho civil y decano del Colegio de Jurisprudencia de la Universidad San Francisco de Quito.
} 


\section{Sumario}

I. Precisión de lo "precontractual": 1. El período de las meras tratativas o tratos preliminares; $\mathbf{2}$. El período de la oferta contractual; $\mathbf{3}$. Los acuerdos de intenciones; $\mathbf{4}$. La situación de los contratos ad referéndum o claudicantes; $\mathbf{5}$. Exclusión de los precontratos o contratos preparatorios.- II. El entorno dogmático del estándar de la buena fe.- III. El tratamiento reductor del artículo 1562 del Código civil.- IV. El deber de buena fe en la fase preparatoria del negocio.-V. La responsabilidad precontractual. Los deberes precontractuales. VI. Naturaleza jurídica de esta responsabilidad: a) tesis de la responsabilidad contractual; b) tesis de la responsabilidad extracontractual; c) tesis de la responsabilidad precontractual; d) La posible concurrencia de los tipos de responsabilidad. VII. Una breve mirada al caso NIFA S.A. vs Merck Sharp $\varepsilon$ Dohme.-

\section{Summary}

I. Accuracy of precontractual elements: 1. Period of preliminary negotiations or preliminary agreements; $\mathbf{2}$. Offer; $\mathbf{3}$. The intention to create legal agreements and agreements to agree; $\mathbf{4}$. Ad referendum agreements; $\mathbf{5}$. Exclusion of precontracts or preliminary agreements.- II The standard of good faith.- III The reductive treatment of Article 1562 of the Civil Code.- IV The good faith in the preliminary phase of the negotiation.- $\mathbf{V}$ The precontractual liability. Precontactual obligations. VI Legal nature of the liability: a) Contractual liability; b) Torts; c) Precontractual liability; d) Concurrence of liability. VII. A brief look at the case NIFA SA Merck Sharp \& Dohme vs from the perspective of pre-contractual liability.

\section{Precisión de lo "precontractual"1}

Con frecuencia el perfeccionamiento de algunos contratos se consuma de manera instantánea, en un solo acto, en el que la oferta o propuesta negocial que lanza uno de los interesados en el negocio va seguida de inmediato por la aceptación del destinatario, quedando de esta manera estructurado el acuerdo de voluntades que da vida jurídica a los contratos que, por eso mismo, se

1 Fue von Ihering (De la culpa in contrahendo o de los daños e intereses en las convenciones nulas o inconclusas, 1860) quien primero observó las propiedades jurígenas de un período precontractual, al analizar la posibilidad de resarcir los daños ocasionados en esta fase, en el derecho romano. Concluyó que el caso parecía ser de responsabilidad extracontractual, pues o se trataba de un contrato no perfeccionado o declarado nulo, mas ello no era admisible en el régimen de daños de la lex aquilia. Tampoco podía serlo de responsabilidad contractual pues en el evento de nulidad debe entenderse que el contrato no ha existido, no obstante lo cual se inclinó por esta última posibilidad teniendo en cuenta que la nulidad si bien impide ejecutar el negocio no excluye una eventual indemnización de los perjuicios. Ver Noemí Lidia Nicolau: Fundamentos de derecho contractual. Teoría general del contrato, Tomo I. Ed. La Ley, Buenos Aires, 2009, pp. 122 y 123. 
denominan consensuales (artículo 1459 Cc) y que constituyen el régimen ordinario en nuestro sistema civil. Algo similar ocurre con los contratos reales, que se perfeccionan por la entrega de la cosa, y en los cuales el consentimiento va de la mano con su entrega y recepción. ${ }^{2}$

Esta inmediatez de la aceptación de la oferta es la regla general contemplada en el artículo 141 del C. de comercio para los casos de oferta verbal, es decir, aquella que se emite entre presentes ("Para que la propuesta verbal de un negocio obligue al proponente, debe ser aceptada inmediatamente por las persona a quien se dirige"). Por asimilación, y bien entendida la norma del artículo 11 de la Ley de Comercio electrónico, debe asumirse que, dadas sus características, es del mismo tipo la propuesta que se expide por vía electrónica. ${ }^{3}$

Ahora bien, esta formación instantánea comúnmente tiene lugar cuando se trata de contratos relativamente sencillos, de escasa importancia económica, relativos a bienes y servicios simples de ordinario intercambio, que por esas características han adquirido una especie de formato social y no suelen, por lo mismo, demandar mucha discusión. También tiene lugar en aquellos con condiciones predispuestas, ordenadas por una de las partes, en los que la discusión queda de antemano y por definición excluida, modalidad negocial que se ha instalado con creciente importancia en el comercio contemporáneo.

Pero no es menos frecuente que la construcción del contrato se vaya desenvolviendo en forma progresiva. En algunas ocasiones ello se debe a que la propia ley impide el perfeccionamiento instantáneo al exigir o la observancia de ciertas formas, como el otorgamiento de una escritura (contratos solemnes), o determinadas esperas como sucede en los casos de oferta escrita a que se refiere el artículo 142 del Código de comercio, ${ }^{4}$ lo que dilata el perfeccionamiento contractual. En otros casos la formación progresiva obedece a que los propios interesados deciden comenzar el tránsito negocial con una fase de conversaciones o tratos preliminares, tratativas o tanteos (les pourparlers de la doctrina y jurisprudencia francesas), porque, como señala un autor, "ambas partes están de acuerdo en que no están de acuerdo" ${ }^{5}$ y por consiguiente se hace indispensable exponer y examinar las pretensiones de cada una sin la intención todavía de contraer un compromiso en regla.

2 En el caso particular del contrato real de mutuo la entrega constituye, además, la tradición de la cosa que se da en préstamo (artículo $2100 \mathrm{Cc}$ ).

3 En efecto, el artículo 11 de la Ley de Comercio electrónico dispone que, salvo pacto en contrario, se presume que el mensaje de datos se emite cuando ingresa "en un sistema de información o red electrónica que no esté bajo el control del emisor o de la persona que envió el mensaje o del dispositivo electrónico autorizado para el efecto"; y que se recibe cuando ingresa "al sistema de información o red electrónica señalado por el destinatario."

4 En tales casos el destinatario de la oferta dispone de 24 horas para aceptarla o rechazarla, si las partes residen en la misma plaza, lapso durante el cual queda suspenso el perfeccionamiento del contrato.

5 Luis P. Leiva Fernández: Responsabilidad precontractual. En El Derecho de los contratos en los umbrales del siglo XXI. Memorias de las Jornadas Internacionales de Derecho de Contratos, celebradas en La Habana, Cuba, en el período 2001-2007. Leonardo Pérez Gallardo, Coordinador. MP Editora, Sao Paulo, 2007, p. 394. 
La sentencia de 19 de diciembre de 2006 de la Corte Suprema de Colombia se refirió precisamente a esta segunda modalidad de formación del contrato:

"...cumple advertir que la formación del contrato implica, en no pocas ocasiones, una fase preparatoria, en desarrollo de la cual los interesados progresivamente definen los términos -principales y accesorios- del contrato mismo que se pretende celebrar, en aras de explicitar su voluntad de cara al respectivo negocio. Sólo en el evento de que la intentio de los participantes sea positiva y coincidente respecto de las bases por ellos proyectadas, se estará en presencia de un acuerdo de voluntades que, en el caso de los contratos consensuales, determinará su celebración o, tratándose de los contratos solemnes, exigirá para su cabal perfeccionamiento, la satisfacción de las correspondientes formalidades legales. Si la voluntad de los interesados, o de alguno de ellos, es negativa, o disímil en algún punto -determinante- materia del negocio, no tendrá lugar el surgimiento o floración plena del contrato en el cosmos jurídico."

Ahora bien, ese camino -o iter- negocial puede estar circunscrito a simples tratos preliminares o "tratativas", mediante los cuales los intervinientes, de ordinario, básicamente exploran recíprocamente sus posiciones e intereses en relación con el potencial contrato. Esos contactos o acercamientos, si bien -incluso- pueden conducir al logro de acuerdos respecto de ciertos y especíicos puntos, no suponen, inexorablemente -o in toto-, la celebración del contrato propiamente dicho, el que es corolario de un acuerdo más definido alrededor de sus elementos esenciales y, por contera, vinculante, merced al establecimiento de aspectos neurálgicos en la respectiva esfera negocial." ${ }^{6}$

En esta fase se desenvuelve entonces un curso de discusión durante el cual los interesados formulan declaraciones que obviamente son precontractuales; y en el que es posible identificar dos momentos:

\section{El período de las meras tratativas o tratos preliminares}

El período de las meras tratativas o tratos preliminares, que se inicia con los primeros contactos o aproximaciones de los interesados respecto del negocio que tienen en mente, ${ }^{7}$ y concluye con la expedición de la propuesta u oferta de contrato.

El propósito durante este período es muy variado: hacer cálculos y valorar posibilidades, "para señalar los eventuales términos en los que cabría o convendría concluir el contrato; pero sin proponer en firme una a la otra su conclu-

\footnotetext{
6 Exp. № 1998-10363-01, Aircraft Maintenance Service Corp. vs Aerovías Nacionales de Colombia S.A., Avianca. Vlex.

7 La precisión de este momento de inicio de la fase precontractual se debe al jurista italiano Gabrielle Faggella, pues para Ihering, el padre de la doctrina de la responsabilidad precontractual, comienza con la formulación de la oferta.
} 
sión en tales o cuales condiciones definitivamente determinadas"8, o "llegar a un acuerdo sobre las condiciones generales del contrato", o "reconocer los puntos de divergencia, buscar soluciones idóneas, moderar las pretensiones contrapuestas, resolver el conflicto de los intereses opuestos; o bien, resolver problemas técnicos de difícil solución que requieren el auxilio de expertos antes de asumir un compromiso. ${ }^{10}$

Es muy posible que en el curso de estas tratativas los interesados lleguen a ciertos acuerdos sobre determinados aspectos del contrato - p. ej., el precio de la compraventa, la calidad de la mercadería, o la forma de entrega -, pero esos consensos se caracterizan por ser parciales (carácter determinante en el caso de los contratos consensuales, porque de ser completos estarían perfeccionados el consentimiento y el contrato), y ordinariamente provisionales, expuestos por tanto a modificaciones según el curso de las conversaciones, siempre, claro está, que no se pacten de tal manera que produzcan una razonable confianza de que se encuentran consolidados. Esto último ocurre usualmente en materia de contratos solemnes, en los que se aprueban de manera definitiva todos los elementos del negocio quedando pendiente sólo el cumplimiento de la forma para que se perfeccione el negocio.

\section{El período de la oferta contractual}

El período de la oferta contractual, es decir, de la propuesta seria y completa del contrato. Seria, porque lleva la intención del oferente de obligarse; y completa, ${ }^{11}$ o suficientemente precisa, exigencia esta última que prefiere la Convención de Viena- ${ }^{12}$ porque está dotada de los elementos esenciales del contrato que se propone (p. ej., la cosa y el precio en el contrato de compraventa), de tal manera que baste la simple aceptación de la persona a la que va dirigida, para que el contrato consensual quede perfecto (artículo 145 del Código de comercio). ${ }^{13}$ En los contratos solemnes, aunque se haya producido

8 Manuel Albaladejo: Derecho Civil II, Derecho de Obligaciones. Edisofer SL, 13ª. edición, Madrid 2008, p. 377.

9 Manuel Risueño F.: De las obligaciones precontractuales." En Revista de Derecho y Jurisprudencia, edición bicentenario: Doctrinas esenciales. Derecho civil. Contratos, Tomo I (Manuel Tavolari, Director). Ed. Thomson Reuters Puntolex, 2010, p. 452.

10 Luigi Ferri: Lecciones sobre el contrato. Traducción de Nélvar Carreteros Torres. Ed. Andrés Bello, 2006, p. 29.

11 Arturo Alessandri Rodríguez y Manuel Somarriva Undurraga: Derecho civil. Tomo IV, Fuentes de las obligaciones. Ed. Nascimento, Santiago, 1942, p. 79.

12 Esta es regla contemplada en el artículo 14.1. de la Convención de Viena: "La propuesta de celebrar un contrato dirigida a una o varias personas determinadas constituirá oferta si es suficientemente precisa e indica la intención del oferente de quedar obligado en caso de aceptación. Una propuesta es suficientemente precisa si indica las mercaderías y, expresa o tácitamente, señala la cantidad y el precio o prevé un medio para determinarlos. 2) Toda propuesta no dirigida a una o varias personas determinadas será considerada como una simple invitación a hacer ofertas, a menos que la persona que haga la propuesta indique claramente lo contrario."

13 Von Thur se refiere a la oferta como "la declaración de voluntad recepticia por medio de la cual una 
aceptación de la oferta, la fase precontractual se extiende hasta el cumplimiento de las solemnidades que los perfeccionan, pues mientras ello no ocurra todavía no hay contrato.

Gabriel Fagella (De los períodos precontractuales y de su verdadera y exacta construcción científica, Nápoles 1906), quien se encargó de dar amplitud a la doctrina de la responsabilidad precontractual a partir de la más restringida propuesta de Ihering sobre la culpa in contrahendo, ${ }^{14}$ identifica un tercer momento, que ubica entre los tratos preliminares y la emisión de la oferta: el período de preparación de la oferta, ${ }^{15}$ en el que una de los interesados, o ambos, recogiendo algunos puntos de encuentro, van dando forma a una oferta sin emitirla todavía. A mi juicio esta nueva fase identificada por el jurista italiano se inscribe todavía en las tratativas preliminares, aunque evidencie un grado mayor de avance, porque las partes ya han concluido las discusiones. Lo digo así porque este progreso prenegocial no gravita significativamente en la eventual responsabilidad ulterior (o al menos no más de lo que pueden incidir otros avances en esta etapa), como se verá más adelante.

\section{Los acuerdos de intenciones}

Frecuentes en la práctica para preparar la celebración de un contrato, estas declaraciones carecen de un perfil definido de tal modo que pueden asumir distintas naturalezas en función de sus contenidos específicos en cada caso, lo que ha motivado diferentes percepciones doctrinarias. Son pactos mediante los cuales las partes se comprometen a llevar adelante las negociaciones encaminadas a la celebración de un contrato cuyos elementos esenciales no están suficientemente determinados y que por alguna razón no están en condiciones de celebrar actualmente. Si se trata solamente de eso no hay dudas de que constituyen una forma de tratativas no vinculantes, que deben ubicarse en la fase precontractual, posición que parece prevalecer en la doctrina jurídica; ${ }^{16}$ pero si el compromiso es asumido con fuerza obligatoria respecto de un contrato que está perfectamente configurado en el acuerdo y se reúnen

persona propone a otra la celebración de un contrato, en términos tales, que para que éste quede cerrado basta con que el destinatario de la oferta la acepte. Esto quiere decir que la oferta ha de ser lo bastante completa y precisa para que de ella se derive con la suficiente claridad el contenido del contrato futuro. La oferta ha de contener todos los requisitos esenciales del negocio, los essentialia negotii..." (Tratado de las obligaciones. Traducción de W. Roces. Edición al cuidado de José Luis Monereo Pérez. Ed. Comares, Granada, 2007, pp.107-108..

14 En efecto, Ihering había limitado su estudio sobre la responsabilidad precontractual al caso de falta de perfeccionamiento y nulidad de un contrato (Ver nota 1).

15 Isabel M. Zuloaga Ríos: Teoría de la responsabilidad precontractual. Aplicaciones en la formación del consentimiento en los contratos. Ed. Legal Publishing, Santiago de Chile, 2008, pp. 27-28).

16 En este sentido se pronunció la sentencia de 11 de abril de 200 del Tribunal Supremo de España, en la que se dijo que el acuerdo de intenciones es "un acuerdo futuro que no llega, por falta de configuración definitiva, al precontrato unilateral que es la opción y constituye jurídicamente unos tratos preliminares que no vinculan en su eficacia contractual.": " 
además las circunstancias del artículo 1570 Cc, el acuerdo constituye una verdadera promesa de contratar.

\section{La situación de los contratos ad referéndum o claudicantes}

Hay ocasiones en que la declaración de voluntad de uno o ambos contratantes necesita ser integrada por otra declaración de voluntad, en forma de asentimiento o aprobación. Se habla entonces de contrato ad referendum o claudicante, de estructura compleja que combina declaraciones de voluntad distintas puestas al servicio del interés de uno de los agentes o de terceros por quienes actúan los que emiten la declaración. ${ }^{17}$ Para algunos se estaría en presencia de un contrato sujeto a una conditio iuris. En el esquema de los negocios complejos empleado por Betti, en cambio, encajaría en la hipótesis de "negocio unitario que consta de varias declaraciones"18 concernientes al mismo objeto y que son obra de dos o más sujetos" (complejidad subjetiva). ${ }^{19}$ Puesto que estas declaraciones deben confluir en el mismo negocio (dar vida a una misma reglamentación de intereses), la no integración de la voluntad requerida impediría la perfección del contrato. ${ }^{20}$ En consecuencia mientras ello no ocurra las declaraciones emitidas pertenecen a una fase precontractual y no son vinculantes (salvo los casos en que la ley disponga lo contrario).

\section{Exclusión de los precontratos o contratos preparatorios}

No se incluyen en la dimensión de lo precontractual, los precontratos, también llamados contratos preparatorios, como el de promesa de celebrar contrato y el de opción, que si bien se forman para la celebración de un contrato futuro, que es el objetivo estratégico de la operación jurídica, constituyen ellos mismos una modalidad contractual pues generan obligaciones particulares (p. ej., celebrar el contrato prometido) cuyo incumplimiento, por tanto, se inscribe de lleno en la disciplina de la responsabilidad contractual.

17 Jorge Mosset Iturraspe: Compraventa Inmobiliaria, Ed. Ediar, Buenos Aires1976, p. 26.

18 Emilio Betti: Teoría general del negocio jurídico. 2a . Edición, Ed. Revista de Derecho Privado, Madrid, 1959, p. 218.

19 ld., p. 222.

20 El debate sobre el tema fue considerado por la sentencia de 26 de mayo de 2010 de la Cámara Nacional Com., Sala E (Argentina), que finalmente se decantó por la tesis del contrato condicional. Así dijo "se advierte que el contrato celebrado no es ni un precontrato ni un contrato preliminar, ni tampoco un contrato definitivo; se trató, en cambio, de un contrato ad referendum o claudicante pues necesitaba su ratificación por el síndico del concurso de la demandada (...) en tanto todo contrato ad referendum -como fue señalado está sujeto a la ocurrencia de un hecho futuro e incierto, a lo cual queda supeditada su operatividad; trasladado ello al sub lite, en que la condición suspensiva no aconteció (ratificación del contrato por el síndico), indefectible es concluir que el contrato no se concretó y, por consiguiente, los contratantes tienen derecho a repetir lo que han entregado estando pendiente la condición." Sin embargo, el fallo hizo presente que la doctrina de Betti había sido invocada en otro caso por la jueza Kemelmajer de Carlucci (autos "Asociación Mutual de Suboficiales y Agentes de Policía de Mendoza v. Dalvian de 26.03.92). 
En el caso del precontrato de promesa de contratar lo dicho no se discute en nuestro medio, pues su naturaleza contractual está expresamente reglada por el artículo 1570 Cc según el cual la promesa de celebrar un contrato da nacimiento a una obligación de hacer (celebración del contrato prometido) cuando reúne las cuatro circunstancias que allí se enumeran, de manera que tal como ocurre en Chile y Colombia, que cuentan con una norma similar (artículos 1554 Cc y 1611 Cc, respectivamente), la doctrina y la jurisprudencia no muestran vacilaciones respecto de este punto. ${ }^{21}$

No acontece lo mismo con el llamado contrato de opción que no está previsto en nuestro Código, como sí lo está en el Código peruano que contempla dos modalidades: la opción unilateral y la opción recíproca, ${ }^{22}$ en el italiano (art. 1331 ) y en el Código de comercio de Colombia; ${ }^{23}$ pero se lo encuentra como figura típica en la opción de compra contenida en el contrato de arrendamiento mercantil o leasing, mediante el cual una parte toma en arrendamiento un bien mueble o inmueble, por un período determinado, a cambio del pago de una renta, con la opción de comprarlo al expirar el arrendamiento, mediante el pago de un precio o valor residual previsto en el mismo contrato. ${ }^{24}$ Sin embargo, la falta de una disciplina general no impide que la opción se asocie a "los más variados contenidos de contrato definitivo: a cualquier intercambio de prestación y contraprestación," 25 al amparo del principio de la autonomía de la voluntad. ${ }^{26}$ La opción vincula a quien la concede, de modo que su incumplimiento da acción al optatario para exigir el cumplimiento forzado y la indemnización de perjuicios.

21 Igualmente claro lo ha dejado la jurisprudencia argentina: “...el contrato preliminar o precontrato es usualmente definido como: “...un pacta de contrahendo, es decir un contrato (puro o condicional), jurídicamente contingente, que obliga a la conclusión de otro contrato (definitivo o preliminar) que regulará los intereses de las mismas partes sustanciales. El contrato preliminar no debe confundirse con las pourparlers que no son un contrato sino simples tratativas para llegar a él y se sitúan en el período precontractual (...) al sostener que el preliminar es un contrato queda definida su naturaleza jurídica normativa...". Por otra parte, el contrato preparatorio es un pacta de modo contrahendo, es decir, este tipo de contrato no obliga a la celebración de otro, pero en él se suministran las bases para su concertación. Son consecuencia de la contratación en masa, propia de los sistemas económicos modernos y responden a la necesidad de uniformidad o standarización de los negocios que se da en la producción y negociación en serie, tales como los contratos reglamentarios/tipos y los normativos" (Cámara Nacional. Com., Sala E, 26 de mayo de 2010).

$22 \mathrm{El}$ artículo 1419 define la primera como aquella en que "una de las partes queda vinculada a su declaración de celebrar en el futuro un contrato definitivo y la otra tiene el derecho exclusivo de celebrarlo o no;" y el artículo 1420 agrega que en el contrato de opción recíproca ella puede ser ejercitada "indistintamente por cualquiera de las partes."

23 Artículo 23 del Código de Comercio colombiano: La opción impone al que la concede la obligación de cumplir su compromiso. Si la opción no estuviere sometida a un término o a una condición, será ineficaz.

La condición se tendrá por fallida si tardare más de un año en cumplirse.

24 Artículo 1 de la Ley de arrendamiento mercantil, leasing, publicada en el R.O. 745 de 5 de enero de 1979.

25 J. L. Lacruz Berdejo et al: Elementos de Derecho civil, Tomo II, Vol. I, $4^{\text {a }}$ edición, Ed. Dykinson Madrid 2007, p. 387.

26 En el caso del contrato de compraventa esta posibilidad está autorizada por el artículo 1827Cc según el cual "pueden agregarse al contrato de venta cualesquiera otros pactos lícitos, y se regirán por las reglas generales de los contratos." 


\section{El entorno dogmático del estándar de la buena fe}

De conformidad con el artículo 1562 Cc, los contratos deben ejecutarse de buena $f e$. El precepto pone en clave positiva un principio cardinal que sirve de entorno a la conducta humana en todas sus relaciones de derecho, pero que exhibe sus más ricas dimensiones y adquiere singular relevancia, en la disciplina del contrato. No exagera Ordoqui Castilla cuando afirma que "la buena fe es el alma de todo contrato." ${ }^{27}$

Así, al referirse a la exigencia de que las obligaciones deben cumplirse de buena fe, la Corte Suprema de Justicia del Ecuador ha dicho que se trata de "una proposición tan clara y evidente que ni siquiera precisa de demostración y constituye postulado fundamental. ${ }^{28}$ Más tarde la Corte puso de relieve le necesidad en que se encuentran las partes de un contrato de "observar deberes de comportamiento que se traducen en prestaciones de dar, hacer o no hacer, cuyo destino es satisfacer un legítimo interés de la contraparte, procediendo de buena fe, realizando no solamente lo que literalmente se expresa en el contrato sino todas las cosas que emanan precisamente de la naturaleza de la obligación emergente del acuerdo de voluntades, o que por la ley o la costumbre le pertenecen a ella." ${ }^{29}$ Y luego el mismo tribunal definió la "regla de la buena fe" como "la conducta que deben observar los contratantes para que sus compromisos sean cumplidos como lo haría una persona honrada y correcta, y se haga así honor a la palabra empeñada, sin defraudar la confianza de los interesados y de la sociedad." ${ }^{30}$

Similar ha sido la posición de la Corte Suprema de Colombia, para la cual la expresión buena fe "indica que las personas deben celebrar sus negocios, cumplir sus obligaciones y, en general, emplear con los demás una conducta leal." ${ }^{31}$

Este estándar es dogma universal y ha sido particularmente desarrollado por el derecho europeo. El artículo 1201.1. de los Principios de Derecho Contractual Europeo impone a las partes "la obligación de actuar conforme a las exigencias de la buena fe", lo que tiene como objetivo "reforzar los niveles generales de honradez, lealtad y razonabilidad en las transacciones comerciales"32,

27Gustavo Ordoqui Castilla: Buena fe en los contratos. Ed- Temis-Ubijus-Zavalia, 2011, p. 31.

28 Corte Suprema de Justicia, $1^{\text {a }}$ Sala de lo Civil y Mercantil, 26 de febrero de 1999. RO 162, de 5 de abril de 1999

29 Corte Suprema de Justicia $1^{\text {a }}$ Sala de lo Civil y Mercantil, 26 de enero de 2000. RO. 27, 29 de febrero de 2000

30 Corte Suprema de Justicia, $1^{\text {a }}$ Sala de lo Civil y Mercantil, 29 de octubre de 2001. RO 471 de 11 de Diciembre de 2001.

31 Corte Suprema de Colombia, sentencia de 23 de junio de 1958. G.J. T. LXXXVIII, pág. 233. En Código Civil comentado, Ed. Leyer, 15ª edición, Bogotá 2006, pág. 1031

32 Principios de Derecho Contractual Europeo, Partes I y II Edición española a cargo de Pilar Barres Benlloch, José. Embid Irujo y Fernando Martínez Sanz. Ed. Colegios Notariales de España, Madrid, 2003. Comentario al artículo 1:201: Buena fe contractual, p. 148.

De acuerdo con el Artículo 1:302 (Definición de lo razonable) de los mismos Principios, "lo que se entienda por razonable se debe juzgar según lo que cualquier persona de buena fe, que se hallare, en la misma situación que las partes contratantes, consideraría como tal. En especial, para determinar aquello que sea razonable, habrá de tenerse en cuenta la naturaleza y objeto del contrato, las 
como, asimismo, conducir a las partes a "mostrar el respeto debido a los intereses de la otra parte." ${ }^{33}$

Por otra parte, este deber de lealtad es recíproco, dirige tanto la conducta del deudor en el sentido del fiel cumplimiento de las prestaciones a su cargo, cuanto la del acreedor, a quien impone aceptar, conforme al mismo estándar, dicho cumplimiento, prestar su colaboración para hacerlo posible y mitigar, en la medida de lo que se pueda, las consecuencias dañosas que se derivan del incumplimiento, tal como lo manda el artículo 9:505 de los Principios citados. ${ }^{34}$ Se trata de una vía de dos direcciones en la que cada persona, anota Larenz, tiene "el deber de emplear para con los demás una conducta leal, una conducta ajustada a las exigencias del decoro social" y, al mismo tiempo, "el derecho de esperar de los demás esa misma lealtad." 35 Para Larenz el principio de la buena fe significa que "cada uno debe guardar "fidelidad" a la palabra dada y no defraudar la confianza o abusar de ella, ya que esta forma la base indispensable de todas las relaciones humanas; supone el conducirse como cabría esperar de cuantos con pensamiento honrado intervienen en el tráfico como contratantes o participando en él en virtud de otros vínculos jurídicos." 36

De allí surge la construcción de una categoría no siempre comprendida: la solidaridad contractual, que "impone a las partes una obligación recíproca de lealtad, dentro de los límites de un sacrificio razonable", a efectos de que la voluntad negocial se forme sin anomalías que impidan valorar adecuadamente lo que efectivamente conviene a sus intereses. ${ }^{37}$

Sin embargo, completa Larenz, el principio de la buena fe es un módulo "necesitado de concreción", ${ }^{38}$ que sirve para orientar la búsqueda de la conducta exigible, pero no nos proporciona reglas concretas de aplicación. Es menester, por tanto, en cada supuesto, hacer "un juicio valorativo del cual se deriva lo que el momento y el lugar exijan." 39

Esta valoración puede hacérsela desde dos direcciones. La primera -buena fe subjetiva- mirándola como un estado de la conciencia del sujeto, la pura

circunstancias del caso y los usos y prácticas del comercio o del ramo de actividad a que el mismo se refiera."(p. 168).

33/d., p. 150.

34 Principios de derecho contractual europeo. "Artículo 9:505: Deber de mitigar el daño. (1) La parte que incumple no responde de las pérdidas sufridas por el perjudicado en aquello que éste hubiera podido mitigar adoptando medidas razonables. (2) El perjudicado tiene derecho a recuperar el importe de aquellos gastos razonables que hizo al intentar mitigar el daño."

35 Karl Larenz: Derecho de Obligaciones, Tomo I, Ed. Revista de Derecho Privado, Madrid, 1958, pp. 142.

36 Ibidem.

37 José Ramón de Verda y Beamonte: La reticencia en la formación del contrato. Aranzadi Civil, Vol. III, Parte Estudio, pp. 197-236.

38 Id., p. 143.

39 Ibidem. 
creencia de que se está haciendo algo correcto, legítimo, con prescindencia de que ello sea o no así. ${ }^{40}$ Es lo que ocurre en materia de posesión, donde la exigencia de la buena fe, para la posesión regular, atiende a un estado sicológico: la conciencia de haberse adquirido el dominio (artículo 721 Cc). La segunda -buena fe objetiva- pone la atención sobre lo que se predica como conducta socialmente exigible, lo que se espera razonablemente de una persona normal, el ciudadano medio, el buen padre de familia, sin detenerse mayormente en la convicción del sujeto cuya conducta particular se escruta.

Esta última es la dirección de la buena fe contractual. Su contextura objetiva obedece a reglas que normalmente no están descritas en el ordenamiento y difícilmente podrían estarlo. Galgano las califica con acierto como reglas consuetudinarias que "corresponden a aquello que un contratante medianamente correcto y leal se siente en el deber de hacer o de no hacer", teniendo en cuenta "el nivel medio de corrección del concreto sector económico o social a que el contrato se refiere." ${ }^{\prime 1}$ Un buen ejemplo de esta objetivación se encuentra en la sentencia de 24 de junio de 1969 del Tribunal Supremo de España que, refiriéndose a la manifestación de voluntad, señaló que ella debe entenderse en el sentido que le es propio "y que le atribuye la generalidad de las gentes" de manera que el emisor "puede confiar en que la parte contraria realizará las obligaciones dadas a conocer de ese modo, y, sobre todo, que cuando el juez tenga que determinar como intérprete la prestación, fallará también ateniéndose al sentido usual."

No obstante, como lo señaló la sentencia de 5 de junio de 2007 de la Cámara de Apelación Civil y Comercial de Lomas de Zamora, Argentina, el derecho no descuida del todo el enfoque subjetivo de la buena fe, porque, en efecto, protege las creencias y expectativas de los contratantes:

"La buena fe -señala el fallo aludido- es un standard jurídico, un patrón de conducta indicativo de la orientación que el derecho pretende dar al individuo en sus relaciones intervinculantes y que se proyecta sobre dos campos: el de la probidad y el de la creencia...El primer caso concierne a situaciones objetivas e impide cualquier abuso de derecho. $\mathrm{O}$ sea que el imperativo de obrar de buena fe impone a los contratantes el deber de hacer todo lo necesario para que la prestación a su cargo tenga un resultado útil...El segundo caso concierne a situaciones subjetivas, protegiendo las creencias y expectativas de los contratantes. Vale decir que el ordenamiento jurídico protege al contratante que de buena fe ha actuado conforme a la apariencia de una situación jurídica exter-

40 Jorge López Santamaría: Los Contratos, Parte General, Tomo II. Ed. Jurídica de Chile, 2005, p. 398

41 Francesco Galgano: El negocio jurídico. Traducción de Francisco de P. Blasco Gascó y Lorenzo Prats Albentosa. Ed-Tirant lo Blanch, Valencia, 1992, p. 454 
namente válida, aun cuando en realidad no lo fuera. Quien produjo esa apariencia haciendo que el co-contratante confíe en ella observando la diligencia propia del tráfico es quien debe soportar sus efectos." ${ }^{42}$

\section{El tratamiento reductor del artículo 1562 del Código civil}

Sin duda el artículo 1562 de nuestro Código, según el cual "los contratos deben ejecutarse de buena fe", cobija el principio universal que, con residencia original en el derecho romano, recibió un poderoso impulso en la sede moralizadora del derecho canónico. Es el soporte de la ética negocial: in omni contractu bonan fidem praestare debit, rezaba la sentencia de Paulo recogida en el Digesto ("en todo contrato debe darse la buena fe"). Expresa lo que Barros Bourie denomina moral del deber cuyo objetivo "no es hacer de cada persona un héroe o un santo, sino un ciudadano cumplidor de los requerimientos básicos que plantea la vida social (...) De lo que se trata es de excluir el abuso y la mala fe y no de prescribir el altruismo y la perfección." ${ }^{43}$

Pero tal como está planteada, la norma del artículo 1562 resulta sumamente reductora, porque los contratos, y los negocios jurídicos en general, no sólo deben ejecutarse, sino también prepararse y concluirse de buena fe, como se lee en otros cuerpos normativos, entre ellos, los códigos civiles de Italia, Portugal, Paraguay y Perú..$^{44}$ En otras palabras, este deber de lealtad -y el correlativo derecho a exigirla- acompañan toda la derrota del negocio, una constante que cruza y modula la existencia de las relaciones jurídicas privadas, como lo expresa el artículo 111-7 del Código Civil de Cataluña. ${ }^{45}$. La jurisprudencia chilena se ha

42Causa 63.223-J.8-R.S.D. № 207/07, 5 de junio de 2007.

43 Enrique Barros Bourie: Derecho y moral, en Revista de Derecho y Jurisprudencia, tomo 80, 1983 , primera parte). Citado por JORGE LóPEZ SANTA MARÍA (obra citada, tomo II, P. 403)

44 Artículo 1337 del C. civil italiano: Trattative e responsabilitá precontrattuale. Le parti, nello svolgimento delle trattative en ella formazione del contratto, devono comportarsi secondo buona fede.

C. civil portugués: ARTIGO 227. (Culpa na formação dos contratos)

1. Quem negoceia com outrem para conclusão de um contrato deve, tanto nos preliminares como na formação dele, proceder segundo as regras da boa fé, sob pena de responder pelos danos qu culposamente causar à outra parte.

C. civil de Paraguay. Art.689.- En el desarrollo de las negociaciones y en la formación del contrato, deben las partes comportarse de acuerdo con la buena fe.

C. civil peruano, Art. 1362.- Los contratos deben negociarse, celebrarse y ejecutarse según las reglas de la buena fe y común intención de las partes.

Menos completa, aunque más amplia que la nacional, es la fórmula del artículo 1198 del Código civil argentino, según el cual los contratos deben celebrarse, interpretarse y ejecutarse de buena fe. 45 Art. 111-7. Buena fe. En las relaciones jurídicas privadas deben observarse siempre las exigencias de la buena fe y de la honradez en los tratos.

Sobre el particular escribe Carlos Morales Guillén, comentando el artículo 520 del Código civil boliviano: “...es principio supremo y absoluto que domina todo el derecho de obligaciones, el de que todas las relaciones de obligación, en todos los aspectos y en todo su contenido, están sujetas al imperio de la buena fe." (obra citada, tomo I, p. 741).

En la sentencia argentina de 5 de junio de 2007 citada más arriba, se expuso: "Como es bien sabido - y el ámbito de las relaciones comerciales no escapan a la regla, ni mucho menos - los contratos deben celebrarse, interpretarse y ejecutarse de buena fe y de acuerdo con lo que verosímilmente las partes entendieron o pudieron entender, obrando con cuidado y previsión (art. 1198, 1a. Parte del Cod. Civil). Se trata de un precepto que ha establecido al respecto algunas pautas que adecuan el principio legal a los casos concretos; así, en supuestos como el presente. la buena fe exige que los 
pronunciado en el mismo sentido, como se advierte en la sentencia de 4 de abril de 2006 de la Corte de Apelaciones de Santiago:

"Que la buena fe es un principio general del derecho, que encuentra plena manifestación en el ámbito de las relaciones contractuales. En efecto, la exigencia de la buena fe en la ejecución de los contratos (consagrada en el artículo 1546 del Código Civil) ${ }^{46}$ impone a los contratantes el deber de comportarse correcta y lealmente en sus relaciones mutuas, desde el inicio, en las tratativas preliminares, hasta los momentos posteriores, incluso a la terminación del contrato. En la fase precontractual, la buena fe está representada por el deber de informar que tienen ambos contratantes acera de todas las condiciones que rodean el contrato que se pretende celebrar y exige que cada uno de ellos presente las cosas conforme a la realidad. La actitud exigida es la de hablar claro (como dice López Santa María, año 1986, pág. 295), lo que implica no sólo abstenerse de afirmaciones equívocas o inexactas, sino también de silencios o reticencias que pueden conducir a una equivocada representación de los elementos del contrato." ${ }^{47}$

Un comentario crítico del mismo tipo hace Oviedo Albán respecto del artículo 1603 del Código colombiano, igual al 1562 nacional, concluyendo que en su estatuto, aunque no esté explícito, "también se incluye el deber de observar la buena fe en los tratos preliminares" para lo cual pone por delante el principio general de que todo el que causa un daño debe repararlo, "cuestión que sin duda puede suscitarse en dicha etapa del iter contractual." ${ }^{48}$

Otro tanto ocurre con Gamarra en su estudio sobre la buena fe en los contratos, al comentar el artículo 1291 del Código de Uruguay, cuyo inciso segundo también es de tenor muy similar al 1562 ecuatoriano. El tratadista uruguayo sostiene que la responsabilidad precontractual se sustenta en la buena fe aunque no haya texto expreso que lo proclame, porque del espíritu del régimen normativo del contrato se colige que, por analogía, el deber de buena fe está

contratantes observen exactamente las obligaciones pactadas; es decir que están vedadas las pretensiones sorpresivas o a destiempo, en razón de la lealtad que debe presidir las relaciones concertadas; la buena fe en la ejecución de los contratos consiste en determinar de manera objetiva la intención de las partes, ajustándose a lo efectivamente querido o previsto y no caer dentro del art. 953 del Cod. Civil...La regla moral que impone la buena fe en la celebración, interpretación y ejecución de los contratos (art. 1198, C.C.), es un principio que integra el orden público porque tiende a obtener o a mantener las condiciones de sustentación que se reputan indispensables para que el contrato funcione ordenadamente como instrumento de justicia (SCBA, AC 78160 S 19-2-2002, CARATULA: Tomas Hermanos y Cja. S.A. c/ Fuentes, Julio C. y otra s/ Escrituración. SCBA, AC 85248 S 10-9-2003, CARATULA: Rocco, Sergio Alberto c/ C.L.Y.F.E.M.A. s/ Cobro de pesos y embargo preventivo)...Por otra parte, es dable exigir a los contratantes un comportamiento coherente, ajeno a los cambios de conducta perjudiciales, y debe desestimarse toda actuación que implique un obrar incompatible con la confianza que merced a sus actos anteriores se ha suscitado en la otra parte."

46 Dicho artículo es del mismo tenor que el 1562 del Código civil nacional.

47 ID vLex: 218052253. http://doctrina.vlex.cl/vid/irribarra-varela-leontina-rector-inacap-218052253. 48Jorge Oviedo Albán: La formación del contrato. Ed. Temis S.A., Bogotá, 2008, p. 12. 
implícito en la etapa precontractual. En ella, dice Gamarra, "se produce una vinculación entre dos sujetos y, por tanto, no es posible pretender que esta normativa de comportamiento rija sólo después del perfeccionamiento. Lo que vuelve aplicable el principio de la buena fe no es una relación obligacional sino la relación social que tiene lugar entre dos sujetos. ${ }^{49}$ Ordoqui Castilla, en cambio, operando sobre el mismo plexo normativo, discrepa que la exigencia de la buena fe en la fase precontractual obedezca a la existencia de la relación o contacto social a que alude Gamarra. Opina que para este efecto no es necesario recurrir a interpretaciones analógicas de normas positivas pues es suficiente acudir a la "vigencia plena del principio general y superior de la buena fe que opera como principio general del derecho. ${ }^{50}$

Pero dejando de lado esta polémica que no compromete el fondo del asunto y no obstante el tenor restrictivo del artículo 1562, lo cierto es que los contratos también deben prepararse de buena fe y así lo dijo la sentencia de 11 de mayo de 2009 de la Corte Nacional de Justicia del Ecuador en la que se reconoció que la buena fe se manifiesta durante la fase precontractual, así como durante la ejecución de un contrato, ${ }^{51}$.doctrina que ya estaba presente en la sentencia de 12 de junio de 2007 de la Corte Suprema de Justicia (la predecesora de la CNJ), en la que se declaró que la buena fe es un principio que gobierna "en general, el derecho de las obligaciones", ${ }^{52}$.y que se ha planteado últimamente con mucho vigor en la sentencia de 10 de noviembre de 2014 de la Sala de lo Civil y Mercantil de la Corte Nacional que se comenta al final de este trabajo (caso NIFA S.A. vs MERCK SHARP DOHME).

\section{El deber de buena fe en la fase preparatoria del negocio}

El contrato es un mecanismo dinamizador de los derechos subjetivos, en tanto permite a sus titulares poner en actividad las potestades que les son inherentes. Siendo así, parece apenas elemental, hay que agregar ahora, que esa dinámica debe ser legítima, es decir, que la actividad negocial de un individuo no sólo se ajuste a la ley (cuestión que tiene que ver con la licitud), sino también a las exigencias capitales y no siempre escritas de la honestidad y lealtad respecto de las personas que se vinculan jurídicamente a ella, de manera que

49 Tratado de Derecho civil uruguayo, T.XI. Citado por G. Ordoqui Castilla: obra citada, Buena fe..., p. 36.

50 ld., p. 38.

51 Sala de lo Civil, Mercantil y Familia, juicio 149-2007, La Unión Compañía Nacional de Seguros contra Transmupan Panalpina Transportes Panalpina S.A. y otros. Suplemento del Registro Oficial 144 de 10 de mayo de 2011: "Es además un contrato (el de seguro), en el cual la buena fe ocupa un lugar fundamental, precisamente porque el asegurado no tiene ánimo de lucro, y porque ella (la buena) se manifiesta desde la etapa precontractual y obviamente durante su ejecución".

52 Segunda Sala de lo Civil y Mercanil, 219-2007, juicio Gráficas Feraud S.A. contra Bolívar Compañía de Seguros S.A. Registro Oficial Suplemento 78 de 1 de diciembre de 2009: "Como ha expresado la doctrina: 'Uberrimae bona fidei', elemento que no es exclusivo del seguro sino que domina en general el derecho de las obligaciones". 
el negocio resulte ética y socialmente admisible porque se ha realizado satisfactoriamente la finalidad a la que obedecen su celebración y tutela jurídica.

Con la comprensible salvedad de aquellas hipótesis más bien triviales que los romanos llamaron dolus bonus, o malicias simples usadas en el comercio cotidiano, como las alabanzas exageradas de la propia mercancía,,53 el paradigma del sujeto negocial corresponde a un individuo recto, leal, fiel a la palabra empeñada, respetuoso de la verdad, prudente en el ejercicio de sus derechos. La actitud exigible al negociador de un contrato, advierte López Santamaría, "es la de hablar claro, absteniéndose de afirmaciones inexactas o falsas, como igualmente de un silencio o reticencia que pueda conducir a una equivocada representación de los elementos subjetivos u objetivos del contrato que se vislumbra. ${ }^{54} \mathrm{Y}$ en este punto es digno de destacar que en nuestro ordenamiento positivo la imagen descrita haya dejado de ser una pura idealización doctrinaria, para convertirse en la descripción del ciudadano real, al que el artículo 83 de la Constitución impone aquellas conductas de rectitud como auténticos deberes jurídicos, compendiados en las fórmulas ama killa, ama llulla, ama shwa (no ser ocioso, no mentir, no robar) y practicar la justicia y la solidaridad en el ejercicio de sus derechos $y$ en el disfrute de bienes y servicios (numerales 2 y 9). ${ }^{55}$

Parece evidente que también nuestro legislador civil tiene en mente a este sujeto negocial emblemático, para el cual la buena fe debe traducirse inevitablemente en el cumplimiento de lo pactado. Esta articulación entre la buena fe y el cumplimiento lleva de la mano al postulado contrario, según el cual la inejecución de lo convenido se presume de mala fe, de manera que el acreedor no está en la necesidad de probar la culpabilidad de aquél, quedando a cargo del deudor justificar su diligencia y la intervención del caso fortuito o la fuerza mayor para legitimar su incumplimiento. ${ }^{56}$

Por cierto no faltará quien minimice la importancia de esta dimensión ética y atribuya las ideas expuestas a un exceso de candor casi incompatible con la

53 Pedro Bonfante: Instituciones de Derecho Romano. Ed. Reus, Madrid, 5a edición, 2002, Pág. 95. Santos Cifuentes define el como la "sagaz precaución con que cada uno defiende lo suyo, por medio de exageraciones, pequeños engaños y omisiones propias del comercio, pero que, por lo mismo, no es dable considerar que la parte ha sido realmente engañada, ya que tiene medios para conocer la verdad" (Negocio jurídico, 2a edición, Ed. Astrea, Buenos Aires, 2004, p. 515).

54 Obra citada, tomo II, pp. 405-406.

55 Algo similar exigía el artículo 97 de la anterior Constitución Política: decir la verdad, cumplir los contratos y mantener la palabra empeñada $\left(\mathrm{N}^{\circ} 8\right)$; y practicar la justicia y solidaridad en el ejercicio de sus derechos $\left(\mathrm{N}^{\circ} 11\right)$

56 El fundamento se encuentra en el artículo 1715, en virtud del cual basta al acreedor probar la existencia de la obligación. En un sentencia de 26 de enero de 1967 la Corte Suprema de Colombia se pronunció sobre este punto “...aunque a menudo se afirma que el incumplimiento de una obligación hace presumir la culpa del deudor, lo cierto es que dicho incumplimiento constituye por sí solo un acto culposo, o sea que no tiene propiamente el carácter de una presunción de culpa, sino que es una culpa consumada o realizada. Importa anotar asimismo que, comprobada la existencia de la obligación, el acreedor no tiene que demostrar el incumplimiento del deudor, sino que le basta afirmarlo." En Gustavo Contreras Restrepo, Alvaro Tafur González y Arturo Castro Guerrero: Código Civil Comentado. Ed. Leyer, 15ª. edición, Bogotá, 2006, p. 1045. 
materia que nos ocupa. Más de alguno postula que el contrato es una confrontación en la que cada uno los intereses en juego trata de obtener ventajas, de manera que, como si se tratara de un juego de guerra, triunfa quien despliega mejores estrategias y tácticas negociales. Pero no es esa la filosofía ni la finalidad del negocio jurídico. Si tomamos como ejemplo el modelo más representativo de negocio, aquél en que intervienen y se obligan dos partes, como ocurre en los llamados contratos conmutativos, se observa más bien una relación de complementariedad porque cada parte dispone de un bien o servicio que la otra necesita, de allí el intercambio de prestaciones que ambas juzgan equivalentes (artículo 1457). De lo contrario se haría muy difícil, cuando no imposible, el consenso ${ }^{57}$ o concertación. En palabras de Ihering, "la unidad de la voluntad en el contrato (consensus) no es otra cosa que el acuerdo de las partes sobre la coincidencia completa de sus respectivos intereses. "58 Y en cuanto al empleo de estrategias, tácticas, destrezas o habilidades, como quiera llamárselas, para lograr una conveniente conclusión del negocio, no sólo que son legítimas, sino necesarias, pero siempre que se ajusten a la ética del negocio, es decir, respeten la verdad, la decisión de honrar la palabra empeñada y no signifiquen un abuso de la posición social, económica o sicológica de una de las partes.

Cuando falta ese ajuste ético se compromete generalmente, en diferentes formas y grados, la eficacia jurídica que las partes han perseguido con la celebración del negocio, bien sea porque se engaña en forma de maniobras dolosas de tal magnitud que conducen a la nulidad del acto (artículos 1474 y 1698), bien porque el abuso de la posición provoca desequilibrios en las prestacio-

57 Obsérvese, en abono de lo expuesto, que la palabra consentimiento proviene del latín consensus, de sentire cum, es decir, "adhesión recíproca del sentimiento de unos al sentimiento de otros." (M. Ortolán: Compendio del derecho romano. Traducción de Francisco Pérez de Anaya y Melquíades Pérez Rivas. Ed. Helistasta, Buenos Aires 1978, p. 112).

58 Rudolf von Ihering: El fin del derecho. Ed. Heliasta, Buenos Aires, 1978, pág. 24. El párrafo transcrito es una conclusión de su análisis sobre el fin común resultante de la complementariedad de los fines individuales: "la misma naturaleza enseña al hombre a conquistar a otro para los propios fines; consiste en relacionar su propio fin con el interés de otro. El estado, la sociedad, las relaciones, los negocios, toda la vida humana descansa en esta fórmula. Varios hombres no persiguen unidos el mismo fin, más que cuando el interés de todos conduce al mismo resultado. Quizá ninguno de ellos piensa en el fin, como tal fin; todos tienen el espíritu dirigido hacia su propio interés, pero estos intereses están de acuerdo con el fin común, y trabajando para sí, cada uno trabaja al mismo tiempo para los demás...Este interés no existe siempre, desde luego; entonces hay que crearlo artificialmente. Tomemos el caso más sencillo, del de la necesidad del concurso de un tercero par permitir a un particular que consiga su fin. La extensión de mi fábrica exige que mi vecino me ceda una porción de terreno. El único medio de obtener lo que codicio, ya se sabe, es la compra. Por la proposición de compra creo artificialmente en mi vecino un interés para la realización de mi fin, con la condición de que mi oferta sea bastante elevada para que su interés en cederme el terreno domine su deseo de guardarlo. Si sus exigencias rebasan mi interés en adquirir el fundo, no hay concordancia entre nuestros intereses y la compra no se realiza. Para que estos se equilibren, el precio ofrecido debe ser bastante elevado a los ojos de mi vecino, bastante mínimo a los míos, para que la venta sea más ventajosa que el sostenimiento del estado de cosas actual, y entonces la operación se terminará. Esta conclusión prueba que el equilibrio ha sido exacto a juicio de ambas partes." He aquí una visión luminosa, de uno de los más grandes exponentes de la ciencia jurídica moderna, sobre la complementariedad que comentamos. 
nes -enriquecimientos o empobrecimientos injustos- que importan ausencia o ilicitud de la causa, lo que también lleva a la nulidad (artículos 1483 y 1698) o que, en otros casos, autorizan al juez para corregir el desequilibrio (artículos 1560,1830 y 2109). Son numerosos los ejemplos que pueden ilustrar la justeza de estos asertos: si el vendedor da un ligero baño de oro a un anillo para hacer creer al comprador que es de oro macizo, ha traicionado la buena fe, en forma de dolo, y el negocio podrá anularse según los artículos 1474 y 1798; cuando una persona a sabiendas de que otra nada le debe, guarda silencio y acepta su promesa de pago, ha vulnerado el principio de la buena fe, la promesa carece de causa y será anulable con arreglo a los artículos 1483 y 1698; finalmente, si el vendedor abusa de su posición de poder o de la confianza de su comprador y exige el pago de un precio desproporcionadamente alto que desequilibra la economía del contrato, ha faltado a la buena fe, existe lesión enorme y el juez podrá rescindir el negocio o eventualmente reducir el precio, con fundamento en los artículos 1829 y 1830.

También falta a la buena fe la parte que en el proceso de elaboración del instrumento negocial incorpora cláusulas ambiguas u oscuras para confundir a la otra, o las expone de tal manera que le pasen desapercibidas (la famosa "letra pequeña" del contrato). En consecuencia la ley reprime estas conductas con diferentes sanciones de orden civil. Respecto del primer caso, el inciso final del artículo 1582 dispone que no pudiendo aplicarse ninguna de las reglas de interpretación del contrato que se contienen en los artículos 1576 a 1581, las cláusulas ambiguas que hayan sido extendidas o dictadas por alguna de las partes, sea acreedora o deudora, se interpretarán contra ella, siempre que la ambigüedad provenga de una falta de una explicación que haya debido darse por ella. En cuanto al segundo, cuando se trata de los contratos de adhesión frecuentes en el comercio, el artículo 41 de la Ley de Defensa del Consumidor ordena que si el contrato contiene textos escritos con letras o números significativamente más pequeños, éstos se entenderán como no escritos. ${ }^{59}$

59 Art. 41.- El Contrato de Adhesión.- El contrato de adhesión deberá estar redactado con caracteres legibles, no menores a un tamaño de fuente de diez puntos, de acuerdo a las normas informáticas internacionales, en términos claros y comprensibles y no podrá contener remisiones a textos o documentos que, no siendo de conocimiento público, no se faciliten al consumidor previamente a la celebración del contrato.

Cuando en un contrato de adhesión escrito con determinado tamaño de caracteres existiese además, textos escritos con letras o números significativamente más pequeños, éstos se entenderán como no escritos. Las partes tienen derecho de que se les entregue copias debidamente suscritas y sumilladas de los contratos y todos sus anexos. Si no fuere posible hacerlo en el act por carecer de alguna firma, el proveedor entregará de inmediato una copia con la constancia de ser fiel al original suscrito por éste; la copia así entregada se tendrá por el texto fidedigno de lo pactado por todos los efectos legales. (Ley Orgánica de Defensa del Consumidor, publicada en el Suplemento del Registro Oficial $\mathrm{N}^{\circ} 116$ de 10 de julio del 2000). 


\section{La responsabilidad precontractual. Los deberes precontractuales}

\section{a) El deber general de información ${ }^{60}$}

Por el sólo hecho de entrar en negociaciones con miras a la celebración del contrato, escribe von Thur, se constituye entre los futuros contratantes una relación jurídica, de la cual se derivan ciertos deberes que no tienen que ver con el cumplimiento del contrato, que todavía no existe, "sino sobre su conducta mutua en el transcurso de las negociaciones." ${ }^{\prime 1}$ Para el profesor alemán este deber consiste en proporcionar todas aquellas informaciones relativas a las circunstancias decisivas para las resoluciones que deben adoptar las partes, exigencia de sinceridad que varía de acuerdo con la naturaleza del contrato. ${ }^{62}$

Castán Tobeñas precisa que esta obligación alcanza a "cuantos puntos sean precisos, a fin de lograr un consentimiento libre y reflexivo." ${ }^{63}$ Se trata, en síntesis, de que las partes logren un conocimiento adecuado sobre las circunstancias materiales y jurídicas que abrigan al negocio, el estado, uso y aplicaciones del bien o de la naturaleza y alcance del servicio que son materia del contrato en discusión, de tal suerte que, en su momento, puedan concluirlo con eficacia y cumplir satisfactoriamente las obligaciones contraídas. ${ }^{64}$

60 Algunos autores se refieren a otros deberes precontractuales como el de protección o seguridad y el de custodia. El primero, como lo plantea Pablo Valés Duque (Una aproximación al análisis de la responsabilidad precontractual o culpa in contrahendo. En El Derecho de los contratos en los umbrales del siglo XXI. Memorias de las Jornadas Internacionales de Derecho de Contratos, celebradas en La Habana, Cuba, en el período 2001-2007. Leonardo Pérez Gallardo, Coordinador. MP Editora, Sao Paulo, 2007, p. 478) comprendería sería todos aquellos "que recaen sobre el deudor de una prestación principal y que tiene por objeto prevenir o evitar lesiones en la vida o en la integridad física del acreedor" y que se manifiestan especialmente en los ámbitos de la actividad laboral y del transporte. El segundo, en palabras de N. Lidia Nicolau (op. cit., Fundamentos..., p. 127), consiste en "el cuidado de todos aquellos elementos que una parte entrega a la otra con motivo de las negociaciones" como es el caso del automóvil que se entrega para que lo pruebe la persona interesada en comprarlo. En realidad ninguna de estas hipótesis son técnicamente precontractuales. El llamado deber de protección es claramente contractual pues supone la existencia de un contrato (de trabajo o de transporte) a cuya prestación principal se asocia el deber en cuestión. A su turno, el deber de custodia podría estimarse precontractual respecto del contrato que se discute, pero jurídicamente no nace de él sino de un nuevo contrato que celebran las mismas partes y que puede ser de depósito o comodato, calificación que no importa por ahora.

61 Op. cit., Tratado..., pp. 113-114.

62A. von Thur: Derecho civil, Volumen II. Los hechos jurídicos. Trad. por Tito Rava. Ed. Marcial Pons, Barcelona 2005, p. 435.

63 José Castán Tobeñas: Derecho civil español, común y foral, Tomo Tercero, $17^{a}$ edición, revisada y puesta al día por Gabriel García Cantero. Ed. Reus, Madrid 2008, p. 661.

64 Este deber adquiere especial relevancia en los contratos de adhesión y, en general, en los que celebran profesionales y comerciantes cuyos conocimientos en el área del negocio superan ampliamente a los de sus contrapartes. En este sentido, la sentencia de 13 de diciembre de 2002 de la Corte Suprema de Colombia, citada por Hernán Darío Velásquez Gómez (Estudio sobre obligaciones, Ed. Temis, Bogotá 2010, p. 833), se refirió a la transparencia negocial en un contrato de leasing, como principio que "implica explicitar aquellas condiciones del negocio jurídico que, aun siendo connaturales -o familiares- a la operación negocial, deben manifestarse para que el adherente conozca, con claridad y precisión, los términos de su vinculación (...) tanto más si la especialidad y tecnicismo del contrato no permite suponer que deba conocerlos (profano), todo lo cual se halla estrechamente vinculado al insoslayable y aquilatado deber de información que, en guarda de la buena fe, tiene el pro- 
Su fundamento es una vez más el principio de la buena fe que para este concreto efecto puede presentarse también como justicia conmutativa, pues si una de las partes dispone de información relevante para la completa eficacia del futuro contrato y la otra no, carece del equilibrio necesario para que obligue. ${ }^{65}$ "El deber de información sustentado en la buena fe -escribe Ordoqui Castilla- cumple distintas funciones básicas: permite un consentimiento con conocimiento de lo que se dice y, además, coadyuva al restablecimiento de la igualdad entre las partes. Así, se actúa con libertad e igualdad, que son el verdadero fundamento del principio de la autonomía privada." Y concluye:

"Como ya dijimos, en esta instancia el deber de actuar de buena fe no sólo impone conductas negativas, como la de no dañar o no defraudar, sino que impone conductas positivas como la de colaborar, asesorar, dar información, avisos, advertencias sobre peligros, etc. El deber no es sólo de no lesionar al otro con engaño diciendo lo que no es (no hacer) sino que es de hacer, o sea, impedir que el otro se perjudique por no saber, colaborando activamente en la protección de su intereses."66

En la importante sentencia de 10 de noviembre de $2014^{67}$ la Corte Nacional destacó el carácter esencial de este deber:

"En estas tratativas previas, o tendientes a la suscripción de un contrato, el intercambio de información es esencial por cuanto la decisión final depende de que el alcance de las propuestas sea verdadero y eso conlleve a su vez a que el consentimiento eventual de las partes expresado en un contrato, sea ajustado a una realidad no distorsionada por intenciones ocultas de cualquiera de las partes. Este deber de mantener una transparencia suficiente, no se contradice con los intereses legítimos de las partes y es integrante del concepto de buena fe, definido en nuestra legislación."

Se comprenderá que el deber en cuestión adquiere especial estatura en los contratos de adhesión y, en general, en aquellos que celebran profesionales ${ }^{68}$

fesional de este tipo de negocios, con mayor razón cuando funge como predisponente del contenido contractual." En otro fallo (19 de diciembre de 2005), citado por el mismo autor, la Corte sostuvo que "En materia contractual la protección de quienes concurren al negocio jurídico requiere el máximo de transparencia posible, de modo que las decisiones se tomen con plenitud de información relevante. De esta manera un contratante no puede quebrar la igualdad, ni tomar ventaja de la ignorancia del otro, especialmente si la ausencia de información de uno de ellos está originada en el silencio del otro que oculta información disponible, información que por ser esencial debe brindarse oportunas y cumplidamente."

65 Cfr. Lidia N. Nicolau: op. cit., Fundamentos..., p. 126. La autora pone como ejemplo la negociación para la transferencia de un paquete de acciones de una empresa, que impone la obligación de informar al posible adquirente sobre su estado financiero y económico (p. 127).

66 G. Ordoqui Castilla: obra citada, Buena fe..., p. 42.

67 Caso Nifa S.A. contra Merck Sharp Dome (MSDIA). Ver sección final de este trabajo.

68 Por ejemplo, el Código de ética médica (Acuerdo Ministerial 14660, RO. 5 de 17 de agosto de1992) impone a dichos profesionales "la obligación de explicar a sus pacientes, los beneficios de la prestación médica institucional, social o pública; antes de hacerse cargo de su caso." 
y comerciantes cuyos conocimientos en el área de sus actividades superan considerablemente a los de sus contrapartes ${ }^{69}$ En este sentido, la sentencia de 13 de diciembre de 2002 de la Corte Suprema de Colombia, citada por Hernán Darío Velásquez Gómez, ${ }^{70}$ se refirió a la transparencia negocial en un contrato de leasing, como principio que

"...implica explicitar aquellas condiciones del negocio jurídico que, aun siendo connaturales -o familiares- a la operación negocial, deben manifestarse para que el adherente conozca, con claridad y precisión, los términos de su vinculación (...) tanto más si la especialidad y tecnicismo del contrato no permite suponer que deba conocerlos (profano), todo lo cual se halla estrechamente vinculado al insoslayable y aquilatado deber de información que, en guarda de la buena fe, tiene el profesional de este tipo de negocios, con mayor razón cuando funge como predisponente del contenido contractual."

En otro fallo, de 19 de diciembre de 2005), citado por el mismo autor, la Corte colombiana sostuvo que

"En materia contractual la protección de quienes concurren al negocio jurídico requiere el máximo de transparencia posible, de modo que las decisiones se tomen con plenitud de información relevante. De esta manera un contratante no puede quebrar la igualdad, ni tomar ventaja de la ignorancia del otro, especialmente si la ausencia de información de uno de ellos está originada en el silencio del otro que oculta información disponible, información que por ser esencial debe brindarse oportunas y cumplidamente. ${ }^{71}$

Al deber de informar se vincula lógicamente "el deber previo de informarse para poder informar", ${ }^{72}$ es decir, anota Verda y Beamonte, un deber de autoinformación que tiene asimismo sustento en la buena fe contractual y que le impone "desplegar una diligencia regular o media en orden al exacto conocimiento de las circunstancias determinantes de la prestación de su consentimiento ad contractum. De otro modo, so pretexto de proteger la bona fides in contrahendo, se estaría amparando comportamientos negociales negligentes (e ineficientes económicamente) a costa, quizás, de sacrificar otros intereses

69 El artículo 4.4. de la Ley Orgánica de Defensa del Consumidor (Ley 21, publicada en el RO. Suplemento 116 de 10 de julio de 2000) contempla este deber en los siguientes términos:

"Art. 4.- Derechos del Consumidor.- Son derechos fundamentales del consumidor, a más de los establecidos en la Constitución Política de la República, tratados o convenios internacionales, legislación interna, principios generales del derecho y costumbre mercantil, los siguientes:

4. Derecho a la información adecuada, veraz, clara, oportuna y completa sobre los bienes y servicios ofrecidos en el mercado, así como sus precios, características, calidad, condiciones de contratación y demás aspectos relevantes de los mismos, incluyendo los riesgos que pudieren presentar;"

70 Op. cit., Estudio sobre obligaciones..., p. 833,

71 Ibidem.

72 J. Castán Tobeñas: op. cit., Derecho civil...Tomo 3, p. 661. 
más dignos de protección, más valiosos socialmente, porque son generadores de riqueza." ${ }^{73}$ Dicho de otra manera, no hay la obligación de informar a la contraparte aquello que ella mismo está obligada a informarse. ${ }^{74}$ De allí que el deber cesa, entre otros casos, ${ }^{75}$ cuando la parte que podía exigirlo tuvo la posibilidad de conocerla de haber obrado con la diligencia que le impone el contrato según el artículo 1563 CC.

\section{b) El particular deber de información sobre la existencia de vicios que afecten la validez del contrato}

Destaco este deber específico porque está en el origen de la moderna teoría de la responsabilidad precontractual tal como la expuso Ihering, en formato de culpa in contrahendo, quien se refirió a los vicios de incapacidad de las partes (Unfähigkeit des subjects), la ineptitud del objeto (Unfähigkei des objects) y el defecto de la declaración de voluntad (Unzuverlässigkeit des contractlichen willens). Si bien no se encuentra reglado expresamente por nuestro Código como conducta a observar por quienes preparan un contrato, su lógica está presente en el artículo 1699, para los casos de nulidad absoluta, que, a modo de sanción civil por la ocultación de la información, priva de acción al que sabía o debía conocer el vicio invalidante.

\section{c) Finalmente está el deber de lealtad que informa las tratativas preli- minares y cuyo examen es el propósito del presente trabajo}

No se discute que estas tratativas o negociaciones precontractuales carecen de fuerza vinculante en tanto no dan forma todavía a un contrato. Constituyen, al decir de Messineo, "un esquema meramente hipotético, que llegará a ser contrato, en caso de que y en cuanto sobre él, esto es, sobre cada una de sus cláusulas, se produzca el consentimiento de las partes (conditio iuris)." ${ }^{76}$ Mientras tanto, ya se lo dijo, las proposiciones que se cruzan en esta fase, a diferencia de la oferta negocial, apenas persiguen ir delineando los elementos que pueden llegar a convertirse en una verdadera oferta y, por lo mismo, pueden ser más o menos imprecisas y aparecer desprovistas todavía de una intención de obligarse.

Ni el predicado de la buena fe ni la tutela de la confianza obligan a prosperar en el negocio que se discute; ${ }^{77}$ simplemente exigen lealtad incluso en el even-

73 José Ramón de Verda y Beamonte: op. cit., La reticencia...

74 Cfr. Pablo Valés Duque: Una aproximación..., p. 477.

75 Tampoco puede reclamarse el deber de información cuando esta pertenece al ámbito de la esfera privada de modo que proporcionarla ocasione una lesión al derecho y garantía constitucional a la intimidad personal y familiar (artículo 66.20 de la Constitución de la República), o se encuentra resguardada por el derecho o el deber de guardar secreto (secreto industrial, profesional, etc.), o cuando el acceso a la misma es igualmente costoso para ambas partes y el que la posee ha debido hacer una inversión para obtenerla (Cfr. Pablo Valés Duque, ibídem).

76 Francesco Messineo: Doctrina General del Contrato. Tomo I. Ed. Jurídicas Europa-América, Buenos Aires, 1986, p. 309.

77 La sentencia de 10 de noviembre de 2014 de la Corte Nacional de Justicia (caso NIFA S.A. vs MSDIA) dejó claramente establecido que no se sanciona per se, entonces, la finalización de las negociaciones" pues "las partes tienen libertad para contratar. 
to de decidir cada uno poner término a las tratativas. Como advierte Barros Bourie, en este período de negociación la buena fe consiste simplemente en "el propósito efectivo de celebrar un contrato." ${ }^{78}$ Por ello, agrega Ordoqui Castilla, "no se deben mantener negociaciones si no se quiere contratar o si se sabe que esas negociaciones no llegarán a un acuerdo final."79 Delimitada de esta manera la cuestión, está claro que el fracaso de la negociación precontractual es una de las hipótesis previsibles y así debe entenderlo cada uno de los que interviene. Lo que el estándar de buena fe no tolera es que ese fracaso sea desleal, injustificado o intempestivo. Ese es el espíritu que anima al artículo 144 del Código de Comercio.

Por tanto la cuestión que se plantea respecto de estos tratos preliminares no es la posibilidad de exigir el cumplimiento de lo que se ha conversado, incluyendo en ello algunos compromisos que por lo general sólo son avances de la negociación sujetos a confirmación; sino simplemente de establecer la posibilidad de reclamar el resarcimiento de los daños que ocasiona la ruptura de dichas tratativas. Es el caso de la persona que sin una razonable justificación ha roto las negociaciones luego de haber creado en su contraparte la justa expectativa de conclusión del negocio, sea porque decidió intempestivamente abandonarlo o porque ha iniciado o pretende comenzar tratos con otros interesados; del que a sabiendas ha impedido o contribuido, de cualquier otra forma, a que se logre la conclusión eficaz del mismo, bien porque ha conducido las tratativas precontractuales conociendo que existe una causal de nulidad del negocio, ${ }^{80}$ o porque sabe o debería saber que la prestación o prestaciones a que se obliga son imposibles de cumplir; y del que luego de haber concluido acuerdos verbales rehúsa suscribir los instrumentos necesarios para el perfeccionamiento del negocio.

En estas hipótesis se habla de culpa in contrahendo, para sustentar la necesidad de resarcir los perjuicios ocasionados a la parte cuyas expectativas quedaron frustradas, porque el negocio no se perfeccionó, o fue anulado, o resultó imposible el cumplimiento de las obligaciones contraídas. En otras palabras, por haberse lesionado lo que la doctrina denomina el interés contractual negativo. ${ }^{81}$

78 Enrique Barros Bourie, Tratado de responsabilidad extracontractual. Ed. Jurídica de Chile, $1^{\text {a }}$ edición, 2006, p. 1001.

79 G. Ordoqui Castilla: obra citada, Buena fe..., p. 40.

80 De este tipo es una especie de culpa in contrahendo que se descubre en la siguiente cita de Modestino, alusiva a la venta mediante engaño de cosas no comerciables, y que le da a esta figura la estirpe romana que inspiró a Ihering: "El que por ignorancia compró como privados lugares sagrados, o religiosos, o públicos, aunque no sea válida la compra, ejercitará sin embargo contra el vendedor la acción de compra, para que consiga lo que le importó que no fuese engañado." (D. L. XVIII, T. I, $\S 62.1$.

81 Refiriéndose a este tipo de lesión, María Medina Alcoz escribe que "pretende reponer, en términos económicos, las cosas al estado en que estarían si el perjudicado nunca hubiera oído hablar del contrato o no hubiera confiado en su validez (id quod interest mihi interest contractum initum non fuisse). El interés negativo es una fórmula polisensa cuyo resarcimiento se integra, por tanto, por dos partidas diferenciadas: los gastos inútilmente efectuados durante la negocaición infructuosa (daño emergente) y la pérdida de ocasiones alternativas de negocio (lucro cesante)" (Responsabilidad precontractual. Estudio acerca de la ruptura injustificada de los tratos preliminares. Ed. Forum, Lima, 2006, p. 49). 
La cuestión no es tan pacífica: "...chocan aquí dos principios: -escribe Rubio Correa- uno que dice que no habría consecuencia alguna porque no se ha llegado al acuerdo final e integral, y, otra, que argumenta que debe haber una cierta responsabilidad en la parte que rompe los tratos porque la buena fe en la negociación supone siempre una lealtad de relación." ${ }^{82}$

La mejor doctrina se pronuncia a favor de la responsabilidad. En palabras de los Ospina "quien interviene en la celebración de un acto jurídico garantiza tácitamente la validez de este a los otros interesados. De suerte que si por su culpa el acto resulta inválido, debe indemnizar los perjuicios resultantes. La evidencia se encuentra en el inciso segundo del artículo 1498 del C. Civil, conforme al cual la nulidad de un contrato por error acerca de la persona de uno de los contratantes no se opone a que este tenga derecho de pedir la indemnización de los perjuicios en que de buena fe haya incurrido..." Ahora bien, las razones de equidad que informan y justifican la teoría de la culpa in contrahendo son valederas no solamente en los casos de nulidad de las convenciones por error acerca de la persona, sino también de cualquier caso de nulidad por el error y, en general, en cualquier caso de invalidez de una convención por culpa de una de las partes, estando la otra de buena fe." 83

Para Messineo, si bien se trata de negociaciones que en principio no son vinculantes, "obligan en otro sentido: esto es, que, cuando han llegado a tal punto que permita prever que el contrato debería poderse formalizar y una de las partes rompe las negociaciones sin un justo o atendible motivo (culpa in contrahendo, es decir, culpa en el curso de negociaciones contractuales; responsabilidad precontractual), la contraparte tendrá derecho al resarcimiento del daño."

La jurisprudencia chilena lo ha venido sosteniendo desde hace muchos años. En la sentencia de 25 de agosto de 1948, la Corte de Apelaciones de Santiago dijo:

"El Código Civil no establece normas específicas sobre responsabilidad precontractual. Esta, en doctrina, es aquella que nace de la equidad comercial. Obliga a indemnizar los perjuicios producidos por la confianza en la formación del contrato, o del retiro de la oferta de celebrar el contrato propuesto, que vulnera la seguridad dada de que aquél se perfeccionará." 84

En esa línea se ubica el Código de Comercio del Ecuador que se refiere específicamente al caso de retractación tempestiva por parte de quien ha formulado

82 Marcial Rubio Correa: La relación sistemática del acto jurídico, las convenciones y los contratos en el Derecho Civil actual. En Revista Roma e America, Diritto Romano Comune, № 7, 1999. Mucchi Editore, Roma, pág. 138.

83 Obra citada, pp. 200-201.

84 Repertorio de Legislación y Jurisprudencia Chilenas. Código Civil y leyes complementarias. Tomo X. Ed. Jurídica de Chile, $2^{a}$ edición, Santiago, 1998, p. 27. 
la oferta negocial, para imponerle "la obligación de indemnizar los gastos que la persona a quien fue dirigida la propuesta hubiere hecho, y los daños y perjuicios que hubiere sufrido" (inciso primero del artículo 144), permitiendo, no obstante, que el proponente se libere de dicha responsabilidad "cumpliendo el contrato propuesto" (inciso segundo). ${ }^{85}$

Los autores alemanes, siguiendo la huella de Ihering, han desarrollado particularmente la hipótesis del contratante que lleva adelante las tratativas y celebra el contrato conociendo o debiendo conocer la imposibilidad de cumplir la prestación a que se obliga, que disciplinó inicialmente el Código civil alemán cuyo $\$ 307$ contemplaba la indemnización de perjuicios solamente en el caso de conclusión de un contrato cuya prestación es imposible, conociendo o debiendo conocer una de las partes esa imposibilidad. ${ }^{86}$ Posteriormente la doctrina expandió la responsabilidad a los casos de frustración de las tratativas. La denominan responsabilidad por "culpa antes o al concluir el contrato"; $;{ }^{87}$ y hoy día, luego de la reforma al derecho de las obligaciones alemán de noviembre de 2001, va mucho más allá, pues aparece con radical fuerza vinculante, como hipótesis obligacional, en el §311.2 del BGB, según el cual una relación obligatoria puede resultar de "entablar negociaciones contractuales". ${ }^{88} \mathrm{Tam}-$ bién ha sido tratada en los artículos 1337 del Código civil italiano, 465 del Código civil de Bolivia y 227 del Código portugués, que tratan de las Trattative e responsabilitá precontratauale, de la responsabilidad precontractual, y de la culpa na formação dos contratos, respectivamente: ${ }^{89}$

85 En el mismo sentido A. Alessandri Rodríguez y Somarriva Undurraga, comentando una norma similar del Código de comercio chileno (op. cit., Fuentes..., p. 82).

86 BGB. "Art. 307 (interés negativo):

1. Si una persona al concluir un contrato cuya prestación es imposible, supiese o debiese haber sabido que era imposible, está obligada a indemnizar cualquier daño que la otra parte haya sufrido por confiar en la validez del contrato; no, sin embargo, más allá del valor del interés que la otra parte tenga en la validez del contrato. La obligación de indemnizar no surge si la otra parte conocía o debería haber conocido la imposibilidad.

2. Estas disposiciones se aplican mutatis mutandis si la prestación sólo es parcialmente imposible y si el contrato es válido respecto a la parte posible, o si solo una de varias prestaciones alternativas prometidas es imposible."

87 Karl Larenz: op. cit, Tomo I, pág. 106.

88 "§ 311. Relaciones obligatorias negociales y similares a las negociales.

(1) Para la constitución de una relación obligatoria mediante negocio jurídico, así como para la modificación del contenido de una relación obligatoria, es necesario un contrato entre las partes, en la medida en que la ley no dispone otra cosa.

(2) Una relación obligatoria con los debers del § 241, apartado 2, también resulta de:

1. entablar negociaciones contractuales.

2. la preparación de un contrato por el cual, en vista de una posible relación jurídica negocial, concede a la otra parte la posibilidad de afectar a sus derechos, bienes jurídicos e intereses o se los confía, o de

3. contactos negociales similares."

89 C. civil de Italia: Art. 1337. Trattative e responsabilitá precontratauale.- Le parti, nello svolgimento delle trattative e nella formazione del contratto, devono comportarse secondo buona fede.

C. civil de Bolivia: Artículo 465 (Culpa precontractual). En los tratos preliminares y en la formación del contrato las partes deben conducirse conforme a la buena fe debiendo resarcir el daño que ocasionen por negligencia, imprudencia u omisión al advertir las causales que invaliden el contrato. C. civil de Portugal: ARTIGO 227. (Culpa na formação dos contratos) 
Larenz sintetiza esa doctrina en los siguientes términos: "en sentido muy general puede decirse que, tanto antes de la conclusión del contrato, en las conversaciones preliminares como al concluirlo, cada uno de los que en él intervienen está obligado a conducirse con aquella diligencia y consideración al interés de la otra parte que es de esperar según la "buena fe" de su futuro compañero en el contrato." ${ }^{90}$

Por su parte, la jurisprudencia española ha precisado las condiciones que deben estar presentes para configurar esta responsabilidad. En sentencia de 14 de junio de 1999 el Tribunal Supremo se pronunció en el sentido de que la ruptura de los tratos preliminares puede ser calificada como conducta antijurídica y dar paso a la responsabilidad precontractual, si concurren los siguientes elementos propuestos por la doctrina: ${ }^{91}$ a) La suposición de una razonable situación de confianza respecto de la plasmación del contrato; ${ }^{92}$ b) el carácter injustificado de la ruptura de los tratos; c) le efectividad de un resultado dañoso para una de las partes; y, d) la relación de causalidad entre este daño y la confianza suscitada. ${ }^{93}$

1. Quem negoceia com outrem para conclusão de um contrato deve, tanto nos preliminares como na formação dele, proceder segundo as regras da boa fé, sob pena de responder pelos danos que culposamente causar à outra parte.

2. A responsabilidade prescreve nos termos do artigo 498.

90 Op cit., Derecho de obligaciones..., Tomo I, Pág. 108.

91 Sala de lo Civil, Sent. $N^{\circ} 527 / 1999$ de 14 de junio (Fundamento de derecho 2). Id Cendoj: 28079110001999101076

92 Con fundamento en la ausencia de este elemento, la misma sentencia desestimó la demanda de indemnización de perjuicios por ruptura de tratos preliminares planteada por el Ayuntamiento de Alagón (Aragón) contra una empresa con la que había estaba negociando la construcción de un matadero industrial de aves en su jurisdicción, contrato que, como conocía la actora, finalmente dependía del financiamiento que la empresa debía obtener del Ministerio de Agricultura. Como hecho de la causa se estableció que, en efecto, hubo "contactos preliminares" entre la demandada y el Ayuntamiento actor y que se inció entre ambos "una actuación colaboradora dirigida al logro de un fin que a ambos interesaba." Frente a un requerimiento del Ayuntamiento para que la empresa le informara si estaba dispuesta a llevar a cabo el proyecto o si desistía de él, la empresa respondió que su intención dependía del financiamiento oficial esperado y que incluso en el evento de obtenerlo "era bastante improbable acometer la inversión" por la difícil situación económica en que se encontraba su sector productivo. El Juez de primera instancia acogió parcialmente la demanda, lo mismo que la Audiencia Provincial de Zaragoza que en segunda instancia estimó que la demandada estaba incursa en un supuesto de responsabilidad extracontractual por ruptura de tratos preliminares. El TRIBUNAL SuPREMo, luego de exponer los requisitos de esta modalidad de responsabilidad, resolvió que en la especie "no se había producido en ningún momento ese estado de esperanza fundada que hiciera presumir que el contrato se iba a consumar, pues la actuación de la recurrente (empresa demandada) siempre estuvo supeditada a la concesión de las subvenciones; en efecto, si se valora la conducta de las partes y su conexión respecto a la creación de dicha confianza, no cabe omitir la mencionada exigencia de la demandada, como tampoco la precipitación con que, pese a la misma, ha operado a la otra parte..."

En otra sentencia de 16 de mayo de 1988, el mismo Tribunal había aceptado una demanda de indemnización por ruptura de tratos preliminares, considerando que la demandada había generado en el actor esa confianza que constituye el requisito de la responsabilidad precontractual (ver notas al pie 136 y 137).

93De todas estas exigencias sin duda las que presentan mayores dificultades son la relativa a la generación de una razonable confianza, dada la notable indeterminación del concepto, y la relativa a la justificación de la ruptura der las tratativas.

Respecto de la primera, Marcelo Barrientos Zamorano relaciona el deber de confianza "con la per- 


\section{Naturaleza jurídica de esta responsabilidad}

Aspecto particularmente discutido de esta responsabilidad es su naturaleza jurídica, cuestión que, más allá de una primera impresión que la hace aparecer preferentemente académica, reviste una singular trascendencia. Como afirma Medina Alcoz, ${ }^{94}$ haciendo suyas las expresiones del maestro salmantino Mariano Alonso Pérez, no se trata de una mera cuestión conceptual, en cuanto que de su adecuada configuración derivan consecuencias prácticas relativas, principalmente, al alcance de la obligación de indemnizar y al plazo de prescripción para exigir el resarcimiento, aspectos que se examinarán más adelante. Por otro lado, debe advertirse, como de inmediato se apreciará, que entran a jugar aquí cuestiones de nomenclatura que a ratos parecen enunciados vacíos porque no desembocan necesariamente en consecuencias jurídicas acordes con la nominación que se utiliza.

\section{a) La tesis de la responsabilidad contractual}

Alguna doctrina sostiene que aun antes de la formación del contrato se crea una relación jurídica entre quienes intervienen en las tratativas, precisamente por causa de estos tratos. Diez Picazo habla de "la posible contractualización del régimen jurídico de la fase de negociaciones" y atribuye a la responsabilidad precontracual un claro fundamento de carácter contractual. ${ }^{95} \mathrm{El}$ autor colombiano Oviedo Albán cita a este respecto a Adriano de Cupis, para quien "la iniciación de tratos es el hecho del que se deriva la obligación de una parte para la otra, de tener un comportamiento concorde a la buena fe. El daño producido por el incumplimiento de tal obligación es un daño que recibe la denominación de "contractual" en tanto y cuanto tal expresión se aplica extensivamente a todo daño ocasionado por el incumplimiento de una obligación, bien se derive de un contrato o de otra fuente. ${ }^{96}$ Monsalve Caballero se adhiere a esta vertiente doctrinaria y sostiene que cuando las expectativas

suasión que el actuar de una parte hace razonablemente generar en la otra, es decir, la seguridad en el cumplimiento de un negocio jurídico determinado." (Daños y deberes en las tratativas preliminares de un contrato, Ed. Legal Publishing, Santiago 2008, pp. 55-56.

En cuanto a la segunda, Diez Picazo, luego de examinar algunos ejemplos, concluye que "en términos generales, se considera que se encuentra justificada la ruptura de las negociaciones, cuando por la situación objetiva del mercado o por cualquiera otras circunstancias, existe una ocasión de hacer un negocio mejor o existe una mejor oferta. En estos casos, los deberes de lealtad y de buena fe obligan solamente a comunicar estas circunstancias a la otra parte, para que decida si puede o no ajustar sus propuestas a la nueva situación" (Fundamentos del derecho Patrimonial l, 6 a edición. Ed. Thomson Civitas, Navarra 2007, p.323).

La sentencia de 10 de noviembre de 2014 de la Corte Nacional (caso NIFA S.A. vs MSDIA) hizo suyo el criterio de Jorge Oviedo sobre este punto: "las partes no pueden abandonar las negociaciones sin justa causa, cuando una de las partes inicia o prosigue las tratativas con la intención de no concluir el contrato, Según el mismo autor habría culpa cuando se induce a la otra parte a confiar en la conclusión del contrato, y avanzar en las tratativas, sin verificar la real posibilidad o sin haber suficiente determinación en la perfección del contrato."

94 Op. cit., Responsabilidad..., p. 52.

95 L. Diez-Picazo: op. cit., Fundamentos..., pp. 325-326.

96 J. Oviedo Albán: op. cit., La formación..., p. 28. 
"son razonables de modo que un contratante medio del sector del tráfico al que pertenezca el contrato concreto, en virtud de su naturaleza y de las circunstancias concretas contaría que ellas son vinculantes, a pesar de que no se haya concluido el contrato." El punto de partida de su razonamiento es la regla de integración del contrato que en nuestro Código se incluye en el artículo 1562, y en mérito de la cual argumenta que las expectativas legítimas se incorporan al contrato, "al margen de la voluntad de las partes, por exigencias objetivas del propio ordenamiento jurídico. ${ }^{\prime 97}$ No obstante el argumento falla por la sencilla razón de que no puede haber integración contractual si no existe un contrato.

Para Risueño la responsabilidad precontractual no puede incardinarse en la responsabilidad extracontractual, puesto que no es el resultado de una culpa delictual que "supone la violación de un derecho que no se deriva de un vínculo contractual creado por el mismo autor del daño", en tanto la base de la responsabilidad precontractual es "la violación de la seguridad dada al perjudicado por el que se retira, de que el contrato se formará," 98 además de que quien se retira de los tratos ejerce su derecho pues, ya se dijo no tiene la obligación de consumar el contrato. Por tanto, agrega el autor, debe indagarse en los elementos de la responsabilidad contractual, porque aunque no se haya perfeccionado el contrato ha existido un acuerdo de voluntades que dio inicio a la preparación del contrato, que produce un efecto "enteramente análogo a uno de los efectos del acuerdo que constituye el contrato mismo." En consecuencia, concluye Risueño, no es necesario probar dolo o culpa en quien se retira, "sino que bastaría la prueba del hecho de haberse violado la seguridad dada." ${ }^{99}$

La tesis no parece de mucha solidez. Es cierto que el comportamiento de buena fe, como ya se ha dicho, es un deber que el ordenamiento impone para ser observado en el completo proceso contractual, pero solamente se convierte en obligación contractual una vez perfeccionado el negocio y ello en virtud de la norma integradora del artículo 1562 Cc. En el período precontractual no podemos hablar de obligación nacida de contrato, porque no lo hay. Muy por el contrario, como advierten Alessandri y Somarriva, refiriéndose la responsabilidad por retractación de la oferta, ella impide la formación del contrato. ${ }^{100}$

b) La tesis de la responsabilidad precontractual como tertius genium

Algunos autores vienen sosteniendo que en aquellos eventos de culpa en las tratativas previas al contrato, estamos ante una modalidad especial de responsabilidad, que ciertamente no es ni podría ser contractual, porque no

97 V. Monsalve Caballero: Responsabilidad precontractual. Grupo editorial Ibáñez. Bogotá 2014, p. 341.

98 Op. cit., De las obligaciones..., p. 491.

99 ld, pp. 493-494.

1000p. cit., Derecho civil, Fuentes..., p. 82. 
existe contrato ni, por tanto, incumplimiento contractual. Se trataría, por consiguiente, de una responsabilidad precontractual, un tertius genium respecto de la clásica distinción de las responsabilidades contractual y extracontactual.

Es la tesis a la que adhieren Alessandri y Somarriva, como doctrina más admitida, pero con el yerro de considerarla "fundada más bien en elementos de carácter moral, y no de carácter jurídico." ${ }^{101}$ El tratadista español Luis Diez Picazo plantea que esta es una responsabilidad sui generis, originada en el contacto social, de una cierta conexión que crea entre ambos pre-contratantes un estado de recíproca confianza, y apoya su aserto en Alonso Pérez para quien los tratos preliminares no son sino un elemento objetivo de una relación jurídica precontractual o prenegocial de características propias.

El fallo de 28 de junio de 1989 de la Corte Suprema de Colombia se pronunció en un sentido que, sin ser en extremo categórico, puede estimarse adhesión a esta doctrina, pues luego de argumentar que en la etapa de tratativas preliminares las partes intervinientes no se encuentran vinculados por lazo jurídico alguno, concluyó que "la responsabilidad en que podrían incurrir las partes de este proceso, no era de naturaleza contractual sino extracontractual, y más concretamente precontractual. ${ }^{102}$

Resulta sumamente atractiva esta tesis porque visibiliza con potencia la circunstancia de que en este caso la obligación resarcitoria obedece a un hecho dañoso con caracteres muy particulares -la transgresión a una declaración de voluntad que tiene como horizonte la contratación-, lo que de inmediato pone el sello distintivo con la similar obligación que nace de otros hechos de variada índole, como la comisión de una infracción penal, por ejemplo.

Ahora bien, así se coincida con la particular naturaleza de esta responsabilidad civil que la distingue como tercer género de las dos modalidades clásicas, debe reconocerse que presenta dificultades a la hora de examinar sus consecuencias en ordenamientos como el ecuatoriano que carecen de una disciplina positiva sobre la materia. Entre otras cuestiones que resultan problemáticas están el plazo de prescripción y la prueba de la culpa. ¿Deberá aplicársele el plazo de prescripción previsto para los casos de responsabilidad por incumplimiento contractual que ordinariamente es de diez años (artículo 2415 Cc), o el de cuatro años previsto para la responsabilidad aquiliana (artículo 2235 Cc)? ¿Es necesario que el accionante pruebe que la ruptura de las tratativas precontractuales obedece a dolo o culpa del demandado, como en el régimen de la responsabilidad extracontractual (artículo 2229 Cc), o debe presumirse culpable de la manera que ocurre en la responsabilidad contractual (artículo 1563 Cc)?

101 Op. cit., Derecho civil, Fuentes..., p. 83.

102 Citado por Jorge Oviedo Albán, op. cit., La formación..., p. 28. 
No existe, a mi juicio, una construcción argumental que pueda responder convincentemente estas preguntas en uno u otro sentido. Si se trata de un tertium genius que no es ni contractual ni extracontractual, ambos sistemas podrían aplicarse o descartarse con parecida autoridad o arbitrariedad. He ahí la dificultad, frente a la cual autores como Zuloaga Ríos proponen la cómoda pero discutible vía de que en ausencia de una disciplina específica sean "la doctrina y sobre todo la jurisprudencia, según el supuesto y las circunstancias del caso concreto" las que determinen las normas aplicables, "quizá (sic) combinando algunas normas contractuales con otras extracontractuales, siempre en función de la justicia y del respeto a la buena fe como principio general del derecho." 103

c) La tesis de la responsabilidad extracontractual

No obstante lo expuesto, es preciso incardinar ab initio la responsabilidad precontractual en alguno de los tipos reguladas por el ordenamiento, siendo la extracontractual la más acorde con la naturaleza de las tratativas, que es precisamente lo que dijo el Tribunal Supremo de España en la interesante sentencia de 16 de mayo de $1988^{104}$ que ha suscitado comentarios encontrados porque se ha puesto en duda que en el caso se haya tratado verdaderamente de responsabilidad precontractual. ${ }^{105}$ En su parte medular, luego de dar por justificados los perjuicios sufridos por el actor, el fallo estimó que había razones sobradamente justificativas "de la existencia por parte de los demandados de una culpa "in contrahendo" que al faltar aquella relación contractual se nos ofrece como aquiliana puesto que no puede negársele al constituir violación al principio "neminen laedere" que determina la responsabilidad de los demandados..."

103 Isabel M. Zuloaga Ríos: Teoría de la responsabilidad precontractual. Ed. Legal Publishing, $3^{a}$ edición, Santiago 2008, p. 318.

104 STS, Sala de lo Civil, Sección I, Sentencia N 405/1988 de 16 de mayo, Id Cendoj: 28079110011988101478.

105 Se trataba de un empleado de la oficina en Pamplona de una institución bancaria al que su empleador le ofreció un traslado a la oficina de Miami, oferta que fue aceptada en términos de que el Tribunal Supremo estimó que había llegado a concertarse un "contrato compromiso" y que finalmente se frustró por decisión del banco. La sentencia estableció que si bien no logró probarse que algún órgano del banco haya hecho a su empleado "orden o promesa en firme, de forma incondicional y efectiva sobre su traslado...es cierto existieron reiteradas gestiones por parte del actor para obtener ese traslado, que tuvieron favorable acogida en principio... pero sin que nunca llegaran a concretarse en su nombramiento o designación." El Tribunal consideró probado "que el problema del traslado del demandante don Jesús Miguel se trató seriamente, llegándose a un punto en el que dicho señor, con toda lógica y ateniéndose a las noticias que le dieron altos empleados de la indicada sociedad... debió pensar que su traslado a la Oficina de Miami (USA) estaba ya acordado y era además inminente lo que impulsó a los accionantes a adoptar disposiciones que resultaron, ante el fracaso de sus expectativas, claramente perjudiciales para sus intereses" (venta de dos automóviles y excedencia voluntaria indefinida de su esposa de su puesto de trabajo de Auxiliar de Clínica de la Seguridad Social).

Diez-Picazo es del criterio que el Tribunal calificó adecuadamente el caso como culpa in contrahendo (Fundamentos...t. I, p. 321) y comenta que C. Asúa cree que no estaríamos ante este tipo de culpa sino de un problema de ejecución del contrato. Me inclino por esta última tesis porque si luego de emitida una oferta seria (con propósito de vincularse y cumplir) se produce una aceptación igualmente seria que es comunicada al oferente, la cuestión ya no es de tratativas precontractuales sino de un contrato perfecto, verbalmente concertado. 
Por la misma doctrina se decantó la sentencia de 10 de noviembre de 2014 de nuestra Corte Nacional de Justicia en el caso NIFA S.A. contra Merck Sharp \& Dohme (ver secc. VII). La Corte apreció que las negociaciones entre las partes no tuvieron la transparencia suficiente y revelaron "durante todo su curso una apariencia de avance irreal propiciado por la accionada y por supuesto, ese comportamiento resulta punible dentro del universo de cuasidelitos (Artículo 2214 C.C.) que está plenamente definido en nuestra legislación civil por contravenir la obligación de conducirse con buena fe (Artículos 721 y 1562 C.C.)."

Es mayoritaria la doctrina que, con diferentes argumentos, se inclina, a favor de esta tesis. Para Albaladejo, que no admite la autonomía de la responsabilidad precontractual, el desistimiento, justificado o no, de las tratativas precontractuales, por sí solo no tiene por qué perjudicar a la contraparte, aunque efectivamente puede impedirle obtener los beneficios esperados de haberse celebrado el contrato, de manera que la necesidad de reparar aparece únicamente si la ruptura resulta ser un hecho ilícito. Por ello, continúa el profesor español, la obligación de indemnizar carece de autonomía, es un caso más de culpa extracontractual. ${ }^{106}$ El Código civil paraguayo se ha inclinado por esta tesis en su artículo 364: "Los actos nulos y los anulables que fueron anulados, aunque no produzcan los efectos de los actos jurídicos, pueden producir los efectos de los actos ilícitos, o de los hechos en general, cuyas consecuencias deben ser reparadas."

Entre los comentaristas del Código de Bello la sustentan también los Ospina, con ocasión de la retractación de una oferta negocial:

"... al proceder así, dicho proponente no debe olvidar que es obligación suya evitar que su conducta ocasione perjuicios a la persona a quien va dirigida su oferta. De manera que si quiere evitarse todo reproche, antes de retirar la oferta, debe asegurarse de que ella aún no ha dado lugar a que el otro interesado haya comenzado a prepararse para la convención propuesta, haciendo gastos y tomando medidas que, a la postre, le resulten perjudiciales, caso de no celebrarse dicha convención. Proceder de otra manera es obrar a ciegas; retirar una oferta sin saber si este acto será indiferente perjudicial para el otro interesado, equivale a incurrir en culpa manifiesta... aunque la oferta no sea obligatoria, aunque quien la formula tenga el derecho de retirarla antes de la aceptación, su responsabilidad civil se configura clara y naturalmente en la culpa extracontractual o aquiliana (de la Lex Aquilia) en que incurre al no obrar con la diligencia y cuidado necesarios para no perjudicar al destinatario." ${ }^{107}$

106 Op. cit., t. I, p. 378.

107 Guillermo Ospina Fernández y Eduardo Ospina Acosta: Teoría general del contrato y del negocio jurídico, $7^{\text {a }}$ edición. Ed. Temis, Bogotá, 2009, p. 151. 
En el mismo sentido se pronuncia Barros Bourie en Chile:

"Uno de los más importantes desarrollos del derecho de las obligaciones reside precisamente en la definición de deberes positivos de conducta durante la negociación contractual. La materia pertenece a la responsabilidad extracontractual (porque los ilícitos no consisten en incumplimiento de contrato), pero está estrechamente relacionada con la doctrina del contrato, pues se refiere a deberes que surgen durante la formación del consentimiento." ${ }^{108}$

Dicho lo anterior, queda por resolver la ya anunciada cuestión de sus consecuencias concretas en materias como la prueba de la culpa y la prescripción de la acción indemnizatoria.

Hay quienes afirman que en el marco de esta responsabilidad es preciso probar la culpa de la persona a la que se imputa. Así lo sostiene Velásquez Gómez: "Sólo si existe culpa habrá lugar a la responsabilidad por violación del deber general de no causar daño, fundamento de la responsabilidad extracontractual." ${ }^{109}$ En similar sentido se pronuncia Albaladejo apoyándose en la jurisprudencia española. ${ }^{110}$

Es punto para discutir si aquello resulta aplicable en nuestro derecho, habida cuenta de la norma del artículo 144 del Código de comercio que obliga a indemnizar aun en los casos en que la retractación de la oferta sea tempestiva, es decir oportuna o dentro del período que la autoriza el artículo 143 del mismo cuerpo legal (entre el envío de la propuesta y la aceptación), lo que pone de resalto que la indemnización procede en todo evento, con bastante independencia respecto de la culpa. Cierto es que no pueden asimilarse oferta y tratativas, aunque ambas pertenezcan al estadio precontractual, pero también lo es la circunstancia de que el artículo 144 instala un criterio de resarcibilidad que no puede dejarse de lado en el caso de ruptura de los tratos preliminares. Este razonamiento tendría indiscutible cabida si se acepta la autonomía de una responsabilidad precontractual con principios y disciplina propios, distintos de la responsabilidad aquiliana. Mas si se le aplica el régimen de la responsabilidad extracontractual resulta mandatoria la exigencia de la culpa ex artículo 2184 CC y la consiguiente necesidad de probarla por quien pretende la indemnización.

Esto último trae una dificultad adicional: ¿cómo podría el accionante que pretende indemnización de perjuicio probar que la ruptura de las tratativas debe atribuirse a culpa o dolo del demandado que se retiró de las conversaciones (p. ej., solamente pretendía ganar tiempo para hacer una negociación más

108 Enrique Barros Bourie, Tratado de responsabilidad extracontractual. Ed. Jurídica de Chile, $1^{\text {a }}$ edición, 2006, p. 131.

109 Op. cit., Estudio..., p. 832.

110 Op. cit...Derecho civil II..., p. 378. 
ventajosa con un tercero), y no obedece a circunstancias de inimputabilidad, como la fuerza mayor o el caso fortuito (p. ej., ha surgido un impedimento legal para celebrar el contrato que se negocia)? Una prueba de este tipo supone incursionar en el fuero interno de su contraparte, dificultad que lo coloca en una verdadera posición de indefensión si no se aplica un correctivo que ponga sensatez y equidad en el onus probandi. ${ }^{11}$

Creo que este es uno de aquellos casos en que se justifica la aplicación de la regla de la carga dinámica de la prueba o de facilidad o mayor proximidad probatorias, según la cual corresponde probar un hecho a la parte que esté en mejores condiciones de hacerlo, sea por disponibilidad del medio correspondiente o por la facilidad para conseguirlo y aportarlo al juicio. ${ }^{112}$ La regla tiene detractores, ${ }^{113}$ pero goza de creciente aceptación. En España tiene residencia en el artículo 217.6 de la Ley de Enjuiciamiento Civil (LEC) ${ }^{114}$ y respecto de

111 Para Monsalve Caballero no es necesaria la prueba de que el infractor actuó con dolo o culpa "pues la falta de diligencia en la fase in contrahendo es un criterio subjetivo de imputación de la responsabilidad" (op. cit., Responsabilidad..., p. 392). En similar sentido Zuloaga Ríos: "Si no es posible configurar culpa o dolo, ello no impide la procedencia de esta responsabilidad, pues la sola violación de la buena fe precontractual entrará a jugar el papel de fundamento inmediato y de factor de atribución de responsabilidad de carácter objetivo y autónomo (op. cit., Teoría de la responsabilidad..., p. 317).

112 Este criterio es avalado por el catedrático salmantino Eugenio Llamas Pombo (Responsabilidad médica, culpa y carga de la prueba, Madrid 2000), citado por Monsalve Caballero: op. cit., Responsabilidad..., p. 400).

$113 \mathrm{H}$. Devis Echandía cita a Lessona (Teoría de las pruebas), para quien "la imposibilidad no priva del deber de la prueba", y se pronuncia a favor de dicha tesis "si se toma el concepto en un sentido general, es decir, que no puede alegarse imposibilidad personal para suministrar toda clase de pruebas, pues esto solo puede ocurrir cuando el hecho en sí sea imposible metafísica, física o matemáticamente (los dos últimos en opinión de expertos y no conforme al criterio del juez, que puede ser deficiente) o no sea susceptible de prueba"; pero, agrega, cuando la ley exige un medio especial de prueba, ad probationem, "creemos que la doctrina francesa debe aceptarse, aunque no haya norma legal que la consagre, como sucede en Colombia, en el sentido de que, no obstante pesar sobre esa parte la carga de probar tal hecho, se la exima de la necesidad de suministrar ese medio específico." (Teoría general de la prueba judicial, T. I y II, $5^{a}$.edición. Ed. Temis, Bogotá, 2006, pp. 422-423).

Desde un punto de vista más práctico, Hernán D. Velásquez observa que "la carga dinámica, por otra parte, genera serios problemas probatorios pues sólo cuando se ha evacuado la prueba se sabe quién era el que tenía más facilidad de probar, lo que lleva a que cuando se presenta la demanda elemento esencial del proceso que delinea su contenido-, no se sabe quién tiene esa carga." (Estudio sobre obligaciones, Ed. Temis, Bogotá 2010, p. 806).

114 Art. 217 de la Ley de Enjuiciamiento civil (LEC) de España:

"Carga de la prueba.

1. Cuando, al tiempo de dictar sentencia o resolución semejante, el tribunal considerase dudosos unos hechos relevantes para la decisión, desestimará las pretensiones del actor o del reconviniente, o las del demandado o reconvenido, según corresponda a unos u otros la carga de probar los hechos que permanezcan inciertos y fundamenten las pretensiones.

2. Corresponde al actor y al demandado reconviniente la carga de probar la certeza de los hechos de los que ordinariamente se desprenda, según las normas jurídicas a ellos aplicables, el efecto jurídico correspondiente a las pretensiones de la demanda y de la reconvención.

3. Incumbe al demandado y al actor reconvenido la carga de probar los hechos que, conforme a las normas que les sean aplicables, impidan, extingan o enerven la eficacia jurídica de los hechos a que se refiere el apartado anterior.

4. En los procesos sobre competencia desleal y sobre publicidad ilícita corresponderá al demandado la carga de la prueba de la exactitud y veracidad de las indicaciones y manifestaciones realizadas y de los datos materiales que la publicidad exprese, respectivamente. 
ella el Tribunal Supremo español ha mantenido una doctrina uniforme. En la sentencia de 4 de mayo de 2000, tratándose de la prueba del pago del precio de una compraventa de fincas pertenecientes a una heredera fiduciaria de residuo, el Tribunal Supremo dijo que debe flexibilizarse el artículo 1214 Cc., ${ }^{115}$ y poner la carga de probar sobre la parte a la que le sea posible hacerlo si a la contraria le es imposible, como sucede en la prueba en cuestión, lo mismo que si en lugar de imposibilidad, hay dificultad sobresaliente de orden objetivo." 116

Por su parte, la Corte Suprema de Colombia, país donde no ha sido consagrada positivamente esta variante probatoria, resolvió el 30 de enero de 2001, en un caso sobre responsabilidad médica, que:

"...no es posible sentar reglas probatorias absolutas con independencia del caso concreto, pues los habrá donde el onus probandi permanezca inmodificable (...), pero también aquellos donde cobre vigencia ese carácter dinámico de la prueba, para exigir de cada una de las partes dentro de un marco de lealtad y colaboración, y dadas las circunstancias de hecho, la prueba de los supuestos configurantes del tema de decisión. Todo, se reitera, teniendo en cuenta las características particulares del caso: autor, profesionalidad, estado de la técnica. Complejidad de la intervención, medios disponibles, estado del paciente y otras circunstancias exógenas, como el tiempo y el lugar de ejercicio."117

La regla atempera el rigor del onus probandi para introducir un ingrediente de equidad en el frío compartimento de la prueba judicial. Armenta Deu pone como ejemplo clásico que justifica la carga dinámica de la prueba, la que debe rendirse en los juicios sobre responsabilidad médica donde los protocolos que sirven de prueba siempre estarán en manos o disponibilidad del médico contra quien se acciona, ${ }^{118}$ por lo que no sería equitativo ni realista poner el peso de su presentación sobre el paciente que persigue la responsabilidad.

5. Las normas contenidas en los apartados precedentes se aplicarán siempre que una disposición legal expresa no distribuya con criterios especiales la carga de probar los hechos relevantes.

6. Para la aplicación de lo dispuesto en los apartados anteriores de este artículo el tribunal deberá tener presente la disponibilidad y facilidad probatoria que corresponde a cada una de las partes del litigio."

115 Derogado por la LEC que incorporó sus reglas en el Art. 217.2 y 3 recién transcrito.

116 Agregó la sentencia citada: "Por lo que respecta a la prueba de la necesidad en que se hallaba la fiduciaria de vender, es cierto que el tercero que contrata con ella no ha de cargar con la prueba de su realidad si quiere que su adquisición sea válida y eficaz. Pero aplicando los principios acabados de exponer no hay ninguna duda de que al actor le era imposible o muy difícil realizarla, porque la fiduciaria vivió los cuatro o cinco años últimos de su vida con el demandado señor Octavio, su esposa e hijos en el domicilio de ellos, donde la recogieron de la localidad de Baza (Granada) en la que residía hasta casi sus setenta años (hechos segundo y tercero de la contestación a la demanda). En estas circunstancias especiales, es claro que sólo los demandados estaban en condiciones de probar la necesidad de venderles ellos prácticamente la totalidad de su patrimonio."

117 En Hernán D. Velásquez: op cit., Estudio..., p. 806.

118 Teresa Armenta Deu: Lecciones de Derecho procesal civil, $4^{\mathrm{a}}$ edición. Ed. Marcial Pons, Madrid, 2009, p. 166. 
En otros casos el problema probatorio se asienta en la prueba de un hecho negativo, como sucede cuando una de las partes se retira de las negociaciones porque ha recibido una mejor propuesta de un tercero. El deber de lealtad le imponía la necesidad de ponerlo en conocimiento de su contraparte para darle la oportunidad de igualar o mejorar la propuesta, ¿Cómo probar que no lo hizo, para imputarle un retiro "culpable" que justifique la demanda indemnizatoria?

En sus Comentarios al Edicto, Paulo expuso la fórmula que llegó a ser clásica en la materia: ei incumbit probatio, qui dicit, non qui negat. ${ }^{119}$ La doctrina moderna, con algunos reparos, viene aceptando que, en determinadas circunstancias, la regla pauliana debe experimentar alteraciones, de manera que no siempre el que niega resultará exonerado de la carga probatoria, lo cual dependerá, en definitiva, del tipo de negación que formule; ${ }^{120}$ pero le reconoce autoridad cuando se niegan hechos indefinidos (negaciones indefinidas) o de negaciones que no están limitadas en el tiempo, como ocurre, por ejemplo, con la afirmación de que nunca se celebró el contrato de compraventa, o en el caso que ahora nos interesa, que no se informó sobre la mejor oferta de un tercero, hipótesis en la que la prueba se hace imposible para la parte que niega. ${ }^{121}$ Se hace necesario entonces invertir la carga de la prueba para imponerla a la parte que debió observar la conducta positiva de informar.

Finalmente está la cuestión del plazo de prescripción de la acción para el reclamo de perjuicios que en la responsabilidad extracontractual es de cuatro años y que, por no haber razones que justifiquen una conclusión contraria, debe aplicarse a los casos de responsabilidad precontractual. ${ }^{122}$

d) La posible concurrencia de los tipos de responsabilidad.

El profesor de la Universidad de Kiel, Karl Larenz, ha planteado una tercera tesis que, sin ser propiamente ecléctica, porque no aproxima las anteriormente expuestas, utiliza sus elementos para llegar conclusiones diferentes según el contrato haya llegado a perfeccionarse o no. En el primer caso dice Larenz, la responsabilidad por la violación in contrahendo de la buena fe puede ingresar al campo de la responsabilidad contractual y sancionarse como tal. Si, por el contrario, el negocio no llegó a celebrarse no podría hablarse de responsabilidad contractual. ¿Cuál sería entonces, en este segundo caso, el fundamento

119 Digesto, L. XXII, T III, §2

120 Luis Parraguez Ruiz: El negocio jurídico simulado. Ediciones luris dictio, Colegio de Jurisprudencia de la Universidad San Francisco de Quito. Quito 2014, p. 299.

121 Es esta, con la limitación anotada, la antigua doctrina que puede leerse en el Diccionario de Escriche (voz "Prueba"), que reproduce las fórmulas del Digesto y del Código, expuestas en el texto (ei incumbit onus probando qui dicit, non ei qui negat, quoniam factum negantis per rerum naturam nulla probatio est).

122 En contrario Monsalve Caballero quien, consecuente con su postura contractualista en esta materia, sostiene que debe aplicarse al plazo de prescripción de las obligaciones ordinarias (op. cit., Responsabilidad..., p. 402), es decir de 10 años en el caso de nuestro derecho 
de la obligación de indemnizar que recae sobre el culpable? Tomando como referencia la norma del §307 del Código Civil alemán, Larenz apoya esta responsabilidad en la vulneración de un deber de aclaración derivado de la buena fe, pero admite que el tema es discutible y expone el rico debate suscitado sobre este punto en la jurisprudencia y doctrina de su país.

Leiva Fernández también aporta al debate la posibilidad de concurrencia de ambas responsabilidades, pero no dependiendo del momento, como lo expone Larenz, sino del hecho que la ocasiona.

"El supuesto de responsabilidad por ruptura de las negociaciones (y sus variantes: por no respetarse los acuerdos parciales ya logrados, por dolo, y por iniciarse o continuarse las tratativas sin seriedad) y el de nulidad del contrato celebrado, responden a criterios propios de la naturaleza extracontractual...En cambio, responden a pautas de naturaleza contractual los que tienen su origen en vicisitudes de la oferta y la aceptación, y en la ruptura del consentimiento (ya logrado) en los contratos reales no perfeccionados por falta de tradición," pues estos últimos si bien no son contratos constituyen convenciones "por lo que resulta natural aplicarles el sistema contractual, en consideración a que la convención guarda una gran analogía con el contrato." ${ }^{123}$

Finalmente, es importante dejar señalado que las cuestiones principales que interesan a esta responsabilidad precontractual, como la de establecer si se está en presencia de meras tratativas o en un proceso formal de construcción del consentimiento negocial, si aquellas han sido de tal naturaleza que justifiquen o no que una de las partes haya cifrado su confianza en el progreso del negocio, si la retractación es intempestiva o puede justificarse razonablemente, son todas cuestiones de hecho que debe calificar el juez de la causa y que no son susceptibles de revisión por vía de casación. ${ }^{124}$

\section{Una breve mirada a un caso Nueva Industria Farmacéutica Aso- ciada S.A. (NIFA S.A.) vs Merck Sharp Dohme (Inter American) Cor- poration}

La jurisprudencia nacional no ha tenido muchas oportunidades para pronunciarse sobre la responsabilidad precontractual, seguramente por la ausencia de un desarrollo teórico sobre la materia tanto en el mundo académico como en el foro. De allí que la reciente sentencia pronunciada el 10 de noviembre de 2014 por la Sala de lo Civil y Mercantil de la Corte Nacional de Justicia en el

123 Luis F. Leiva Fernández: op. cit., Responsabilidad precontractual..., p. 403.

124 Francesco Messineo: op. cit., Doctrina general..., p. 309. 
juicio No 215-2014, seguido por INDUSTRIA FARMACÉUTICA ASOCIADA S.A. (NIFA S.A.) contra MERCK SHARP DOHME (INTER AMERICAN) CORPORATION, esté llamada a constituir un importantísimo precedente jurisprudencial, pues se refiere a un caso emblemático en el que se han dado cita los elementos más relevantes de esta modalidad de responsabilidad, algunos de los cuales ya se han mencionado en párrafos anteriores.

En el mes de febrero de 2002 las compañías farmacéuticas INDUSTRIA FARMACÉUTICA ASOCIADA S.A. (NIFA S.A.) y MERCK SHARP E DOHME (MSDIA), iniciaron conversaciones para la adquisición por la primera de una planta industrial de propiedad de la segunda, con el propósito de ampliar su capacidad de producción. Las negociaciones avanzaron consistentemente en puntos sumamente sensibles, algunos de ellos relativos a la cosa y al precio, que son esenciales del contrato de compraventa (artículo 1732 Cc), además de la entrega de información sobre la producción de la planta, su equipamiento, compromiso de confidencialidad suscrito por NIFA S.A., sucesivas ofertas de precio, prórroga de vigencia de la oferta final solicitada por MSDIA, entrega por esta última de títulos y documentos habilitantes para la instrumentación de la compraventa, precisión de los detalles de la oferta de compra, información sobre fuentes de financiamiento, entrega del plan de negocios de NIFA S.A, aceptación de ésta a las principales condiciones negociales propuestas por MSDIA, información sobre la situación laboral del personal de MSDIA del que se haría cargo NIFA S.A., etc.

Las conversaciones -típicas tratativas precontractuales, pues las partes estaban conscientes de que no eran vinculantes mientras no se celebrara el contrato de compraventa o de promesa de compraventa, según el caso- no tuvieron mayores tropiezos hasta el mes de enero de 2003 en que sorpresivamente MSDIA impuso a NIFA S.A. una pretensión ajena a lo esencial del contrato de compraventa que se discutía y que hasta entonces no había sido sugerida durante el proceso de negociación que ya llevaba casi un año de duración: la obligación de no fabricar varios productos farmacéuticos que supuestamente producía MSDIA..

NIFA S.A. aceptó esta nueva exigencia únicamente respecto de los productos que no estaban en la lista de genéricos y por un período de dos años. En el mismo mes de enero y sin mediar aviso alguno, MSDIA dio por terminadas las conversaciones y posteriormente vendió la planta a un tercero. A juicio de NIFA todo el proceso de negociación fue una estrategia de MSDIA para demorar su entrada en los mercados de productos farmacéuticos genéricos lo que en efecto ocurrió pues sus planes de expansión en el mercado ecuatoriano se vieron frenados por lo menos dos años como consecuencia de la retractación desleal de su contraparte. 
El proceso de negociaciones precontractuales llegó al punto avanzado de la oferta formal, o para ser más preciso, de una sucesión de ofertas y contraofertas (artículos 145 y 146 C. de comercio), ${ }^{125}$ todas ellas serias y completas, acordes los precontratantes en la cosa y con contrapropuestas en el precio, suficientes para formar el consentimiento contractual con una simple aceptación final, de modo que solamente habría faltado el cumplimiento de la forma legal para perfeccionarlo.

Pero aunque así no fuera, deberá admitirse, por lo menos, que hubo un caso típico de tratativas o tanteos preliminares cuya injustificada retractación debía dar paso a la responsabilidad civil de MSDIA. La defensa de MSDIA insistió en que las conversaciones llevadas adelante con la demandante no podían haber generado obligaciones para las partes porque no se había suscrito un contrato solemne de compraventa, argumento idóneo si la actora hubiera pretendido demandar obligaciones contractuales, pero inepto para resolver una disputa de responsabilidad precontractual. Adicionalmente la forma en que se desarrollaron las negociaciones generaron en NIFA una razonable confianza en que MSDIA concluiría finalmente el negocio. En esa confianza NIFA no buscó soluciones alternativas para su proyecto de ampliación, de modo que la ruptura le ocasionó importantes perjuicios.

La demanda de NIFA se fundamentó, entre otras, en la norma del artículo 2214 CC sobre responsabilidad extracontractual que, como se ha dicho, es lo que corresponde en las hipótesis de responsabilidad precontractual, de manera que podía asumirse que la actora pretendía resarcimiento con fundamento en esta responsabilidad. También invocó los numerales 1 y 3 del artículo 244 de la Constitución Política entonces vigente, relativo, el segundo de los mencionados, al "desarrollo de actividades y mercados competitivos."

Planteadas así las cosas, en sentencia de 17 de diciembre de 2007 la Jueza Segundo de lo Civil de Pichincha estimó que a la luz de lo dispuesto en el numeral 3 del artículo 244 de la Constitución Política, la conducta de la demandada constituía una práctica anticompetitiva y por lo mismo un ilícito civil, por lo que admitió la demanda de NIFA S.A. y condenó a MSDIA al pago de una indemnización de US\$200.000.000. Subida en grado, la sentencia de 23 de septiembre de 2011 de la Primera Sala de lo Civil, Mercantil, Inquilinato y Materias Residuales de la Corte Provincial de Pichincha confirmó la sentencia de primera instancia reformando el sin duda elevado quantum indemnizatorio que redujo a US\$150.000.000. Se fundamentó, asimismo, en la norma del numeral 3 del artículo 244 de la Constitución que pone de manifiesto que el constituyente de 1998 "determinó que las prácticas monopólicas y otras que impiden o distorsionan la libre competencia son ilícitas", razón por la cual procede el

125 Código de comercio: Art. 146.- La aceptación condicional o las modificaciones a la propuesta, se tendrán como propuesta. 
resarcimiento de perjuicios con fundamento en la norma abierta del artículo 2214 del Código Civil. Propuesto el recurso de casación por MSDIA, la Sala de lo Civil y Mercantil de la Corte Nacional de Justicia casó la sentencia recurrida y condenó a "Merck Sharp E Dohme al pago de una indemnización de US\$ 1.570.000 "por el cuasidelito civil de negativa de venta por actos de desorganización del competidor dentro del Derecho de la Competencia "incurrió en prácticas que impiden o distorsionan la competencia (...) la cual da lugar a un cuasidelito civil" (sentencia de 21 de septiembre de 2012). NIFA S.A. dedujo acción extraordinaria de protección ante la Corte Constitucional que en sentencia de 12 de febrero de 2014 declaró vulnerado los derechos al debido proceso, a la tutela judicial efectiva y al derecho a la seguridad jurídica y ordenó, como medida de reparación integral, dejar sin efecto el fallo de 21 de septiembre de 2012 de la Sala de lo Civil y Mercantil de la Corte Nacional de Justicia, y que dicha Sala dicte nueva sentencia de casación. Esta se pronunció el 10 de noviembre de 2014 y en ella la Sala casó parcialmente la sentencia dictada el 23 de septiembre de 2011 por la Corte Provincial de Pichincha y condenó a MSDIA al pago de una indemnización de US\$ 7.723.471,81. ${ }^{126}$

Lo relevante de esta nueva sentencia es que el Máximo Tribunal de la República dejó de lado el debate que las anteriores sentencias habían centrado en distintos aspectos del Derecho de la Competencia, para incursionar decidida y profundamente en la doctrina de la responsabilidad precontractual. En sus pasajes más significativos, que están contenidos en el Considerando OCTAVO ("Problema jurídico"), la Corte abordó con detenimiento los aspectos cruciales de esta responsabilidad, para precisar el concepto de tratos preliminares, la necesidad de llevarlos a cabo con apego al principio de la buena fe, la ruptura injustificada de las negociaciones y su consecuencia indemnizatoria. Sobre estas cuestiones, además de lo que se ha citado en el curso de este trabajo, la Corte dijo:

- En cuanto a los hechos, que la conducta engañosa de MSDIA, al exigir de NIFA S.A. algo que nunca fue parte de la negociación (la inaceptable abstención de producir varios medicamente genéricos), obedeció a una estrategia para demorar la entrada de NIFA S.A. a los mercados de productos genéricos.

- Que "los tratos preliminares, según Stiglitz, son aquellos "...diálogos preliminares que, en el iter negocial, se ubican en una etapa que precede al perfeccionamiento del contrato." ${ }^{127}$

126 Con el voto salvado del juez Paúl Iñíguez que negó los recursos de casación. En dicho voto se recoge la tesis de la práctica anticompetitiva, sin embargo de lo cual se incursiona también en el campo de la responsabilidad precontractual cuando se afirma que la norma del artículo 2214 del Código civil que fundamenta la indemnización concedida en segunda instancia (y que fue invocado en la demanda de NIFA S.A.) "abarca todos aquellos hechos que sean delitos o cuasidelitos, como ilícitos que generan un daño, en el presente caso se rompió un acuerdo de negocios por parte de los demandados, no cumplieron su compromiso, comportando una conducta dañina en perjuicio de la parte actora."

127 Página 45 de la sentencia. 
- "En los tratos preliminares lo que debe prevalecer es la buena fe, si existe mala fe, si se viola el deber de buena fe, con los consiguientes deberes de conducta que de ella se derivan, quien ha actuado, por ejemplo, sin intenciones de llegar a un acuerdo y esto ha causado perjuicios, está obligado a indemnizar." ${ }^{128}$

-"Retener unas negociaciones artificialmente, de modo que estas se rompen posteriormente sin una causa justificada, y cuando la otra parte tenía fundada confianza en que el contrato se celebraría, es infringir la buena fe precontractual." ${ }^{29}$

- El deber de no levantar falsas expectativas "se refiere cuando una de las partes negocia sin las intenciones de contratar, logrando que la otra parte descarte otras oportunidades, es lo que se ha denominado en la doctrina el costo de oportunidad. Se crea confianza sobre hechos o circunstancias que no van a suceder." 130

- "...las partes no están obligadas por estos tratos preliminares a celebrar un contrato, pero sí a actuar de buena fe, la responsabilidad nace cuando se ha actuado de mala fe y se ha perjudicado a la otra parte por la no celebración del contrato, cuando la no celebración de un contrato resulta arbitraria, sin causa o fundamento justo (...) las negociaciones obligan en otro sentido: esto es, cuando han llegado a tal punto que permitan prever que el contrato debería poderse formalizar y una de las partes rompe las negociaciones sin un justo y atendible motivo (...) la contraparte tendrá derecho al resarcimiento del daño -o sea, el llamado interés contractual negativo." ${ }^{131}$

$128 \mathrm{Ibidem}$. 